\title{
Animal models of attention deficit/hyperactivity disorder (ADHD): a critical review
}

\author{
Thomas A. Sontag • Oliver Tucha $\cdot$ Susanne Walitza • \\ Klaus W. Lange
}

Received: 3 August 2009/ Accepted: 2 January 2010/Published online: 29 January 2010

(C) The Author(s) 2010. This article is published with open access at Springerlink.com

\begin{abstract}
Attention deficit/hyperactivity disorder (ADHD) involves clinically heterogeneous problems including attention deficits, behavioural hyperactivity and impulsivity. Several animal models of ADHD have been proposed, ranging from models with neurotoxic lesions to genetically manipulated animals. An ADHD model is supposed to show phenomenological similarities with the disorder, i.e. it should mimic the three core symptoms (face validity). A model should also conform to an established or hypothesized pathophysiological basis of the disorder (construct validity). Finally, an animal model should be able to predict previously unknown aspects of the neurobiology of ADHD or to provide potential new treatments (predictive validity). The currently proposed models are heterogeneous with regard to their pathophysiological alterations and their ability to mimic behavioural symptoms and to predict response to medication. This might reflect the heterogeneous nature of ADHD. Since the knowledge about the biology of ADHD from human studies is limited, one cannot at present decide which model best represents ADHD or certain ADHD subtypes. Animal models with good face and predictive validity may be useful for investigations of the underlying biological substrates of
\end{abstract}

T. A. Sontag $(\bowtie) \cdot$ K. W. Lange

Department of Experimental Psychology,

University of Regensburg, 93040 Regensburg, Germany

e-mail: thomas-alexander.sontag@psychologie.uni-regensburg.de

O. Tucha

Department of Psychology, University of Groningen,

Groningen, The Netherlands

S. Walitza

Department of Child and Adolescent Psychiatry,

University of Zurich, Zurich, Switzerland
ADHD. At present, the models in use should be described as animal models of ADHD-like symptoms rather than models of ADHD.

Keywords Animal models .

Attention deficit/hyperactivity disorder · ADHD

\section{Introduction}

The definition of hyperkinetic disorder according to ICD-10 is based upon the simultaneous presence of three main behavioural problems, i.e. attention deficit, overactivity and impulsiveness. They need to be present in more than one situation and to cause impairment in functioning. The problems need also to have been present before the age of 7 years. The DSM-IV category is called attention deficit/ hyperactivity disorder (ADHD). The criteria are based upon the same list of behaviours as those that characterize the ICD-10 definition of hyperkinetic disorder.

The 4th edition of the Diagnostic and Statistical Manual of Mental Disorders (DSM-IV) describes three subtypes of ADHD, i.e. (1) the predominantly inattentive type, (2) the predominantly hyperactive/impulsive type and (3) the combined type with symptoms of inattention, impulsivity and hyperactivity (American Psychiatric Association 1994). ADHD represents the extremes of normal behaviour in the domains of attention and activity, which makes a clear diagnosis difficult. In addition, several comorbid disorders can be found in children and adolescents with ADHD, including oppositional defiant disorder and conduct disorder (50\%), anxiety disorders (25-35\%), mood disorders (15\%) and learning disabilities (Biederman et al. 1991). In view of the high prevalence of comorbid disorders, clinical, neuropsychological and neuroimaging 
studies of children and adolescents with ADHD will consist of relatively heterogeneous patient groups. It is therefore important to describe the core disorder of ADHD, e.g. by identifying biological markers, which could improve the diagnosis. This may also help to develop new treatment strategies.

The current pharmacotherapy with psychostimulants goes back to 1937 when Bradley discovered that amphetamines ameliorate disruptive behaviour in children (Bradley 1937). All drugs that are found to be therapeutically effective in ADHD affect central catecholaminergic neurotransmission, namely the dopaminergic and noradrenergic systems.

These findings suggest that dysfunctions of catecholaminergic neurotransmitter systems contribute to the symptoms of ADHD. In addition, patients with frontal brain lesions show some behavioural similarities with ADHD patients (Benton 1991; Heilman et al. 1991; Levin 1938; Mattes 1980) and ADHD has been shown to be highly heritable (Bobb et al. 2005; Fisher et al. 2002; Teicher et al. 2000). These findings suggest that ADHD is based on some specific neurobiological dysfunctions.

Several animal models of ADHD have been suggested and discussed (for review see also Kostrzewa et al. 2008; Russell et al. 2005; Sagvolden et al. 2005; van der Kooij and Glennon 2007). The quality of these animal models depends on their ability to mimic the symptoms and to reflect the neurobiology of ADHD. Most models are solely based on similarities in symptoms. Since our knowledge concerning the neurobiological alterations in ADHD remains sketchy, it is too early to propose valid animal models of ADHD. The present review will come to the conclusion that none of the currently discussed models fulfil all necessary validation criteria.

\section{Human studies in ADHD}

\section{Genetics}

Several investigations have shown that genetic factors play a major role in the aetiology of ADHD. The risk to develop ADHD in siblings of an affected child is between $10 \%$ and up to $32 \%$ (Biederman et al. 1992, 1995; Levy and Hay 2001; Smidt et al. 2003). If a parent has ADHD, the risk for offspring to develop the disorder is $57 \%$ (Biederman et al. 1995). In twin studies, it was found that the concordance for ADHD is $81 \%$ in monozygotic twins, compared with $29 \%$ in dizygotic twins (Gilger et al. 1992). The average heritability for ADHD was found to be 0.80-0.90 (Gilger et al. 1992; Rhee et al. 1999). Although high heritability in ADHD has been reported in twin, family and adoption studies, with estimates up to $90 \%$, genome-wide linkage scans and candidate gene studies have so far not been able to reliably identify ADHD-associated genes (Faraone et al. 2005).

Hebebrand and associates (2006) reported evidence for a risk haplotype at the dopamine-transporter (DAT/SLC6A3) locus based on a linkage scan and subsequent finemapping of chromosome 5p13. Several novel susceptibility loci have been detected in a linkage analysis of extended families using 50K single nucleotide polymorphism (SNP) array-based genotyping assay (Romanos et al. 2008), one of these loci, the chromosome 16 locus, contributes to the genome-wide significant finding revealed by a meta-analysis comprising data of seven ADHD linkage scans (Zhou et al. 2008). Although significant linkage signals were identified in some of the studies, there have been limited replications between the various independent datasets. The meta-analysis by Zhou et al. (2008) aimed to identify the genomic region with most consistent linkage evidence across the studies. Genome-wide significant linkage was identified on chromosome 16 between 64 and $83 \mathrm{Mb}$. In addition, there were nine other genomic regions showing nominal or suggestive evidence of linkage.

Several candidate genes have been proposed. The focus was initially on genes coding for the $\mathrm{D}_{2}$ receptor. An association between this gene and alcoholism, Tourette syndrome and ADHD was found (Blum et al. 1996; Comings et al. 1991). However, other studies failed to replicate these results (Fisher et al. 2002; Gelernter et al. 1991; Kelsoe et al. 1989). Another promising gene codes for the dopamine $D_{4}$ receptor. Several studies have suggested that an overrepresentation of this gene is associated with ADHD (Faraone et al. 1999, 2005; Faraone and Doyle 2001; Grady et al. 2003; LaHoste et al. 1996; Li et al. 2006; Swanson et al. 1998). The $\mathrm{D}_{4}$ receptor is predominantly expressed in prefrontal regions, which are thought to be involved in the aetiology of ADHD (Floresco and Tse 2007; Noain et al. 2006). Several mutations on the $D_{4}$ receptor gene have been suggested to be associated with ADHD. The most widely studied polymorphism is the 48-bp VNTR in exon 3. The most common alleles are the 2-, 4- and 7-repeat alleles. A recent meta-analysis by Gizer et al. (2009) has found a significant association between ADHD and the 7-repeat allele. This result is in line with other studies (Faraone et al. 2005; Li et al. 2006). Another polymorphism that has been associated with the $\mathrm{D}_{4}$ receptor, and ADHD is located in the promoter region of this gene. Some studies have found an association between ADHD and the 240-bp-allele in the promoter region of the $\mathrm{D}_{4}$ receptor gene (Kustanovich et al. 2004; McCracken et al. 2000) while other studies were not able to confirm this association (Barr et al. 2001; Todd et al. 2001). Other authors have suggested a role of the $D_{5}$ receptor (Daly et al. 1999; Fisher et al. 2002) or the $\mathrm{D}_{1}$ receptor (Cook et al. 1995; Daly et al. 1999; Gill et al. 1997; Waldman et al. 
1998). The $\mathrm{D}_{1}$ receptor gene might also be associated with different responses to methylphenidate in patients with ADHD (Winsberg and Comings 1999). Genes regulating the dopamine (DA) metabolism might also play a role, e.g. the gene regulating dopamine-beta-hydroxylase appears to be associated with hyperactivity (Mueller et al. 2003). Genes regulating noradrenergic activity, such as the noradrenaline (NA) transporter gene (NAT), have been found to be associated with ADHD (Barr et al. 2002; Wang et al. 1999).

The serotonin transporter gene has been proposed as a candidate gene for ADHD and may be involved in the aetiology of impulsivity (Halperin et al. 1997; Spivak et al. 1999; Stein et al. 1993). One of the most studied polymorphisms of this gene (the 5HTTLPR) is located in the promoter region of this gene. There are two variants, the long variant is associated with a more rapid serotonin reuptake and the short variant is associated with a reduced serotonin uptake (Lesch et al. 1996). A meta-analysis by Gizer et al. (2009) found a significant but modest association between ADHD and the long variant, which supports the importance of this gene in the aetiology of ADHD. In the same study, Gizer et al. (2009) also investigated the serotonin $1 \mathrm{~B}$ receptor and serotonin $2 \mathrm{~A}$ receptor genes. An association between ADHD and the serotonin 1B receptor had been reported by Hawi et al. (Hawi et al. 2002), and this was confirmed in the meta-analysis by Gizer et al. (2009). No association was observed between the serotonin 2A receptor and ADHD (Gizer et al. 2009).

In summary, several genes related to DA, NA and serotonin appear to be involved in the aetiology of ADHD (Bobb et al. 2005; DiMaio et al. 2003; Gizer et al. 2009), Both genome-wide linkage scans and the results of genome-wide association studies are contradictory concerning the 'classic' genes of the dopaminergic (e.g. DAT/SLC6A3; COMT), noradrenergic and serotonergic pathways (Lesch et al. 2008; Franke et al. 2009). Other genes not related to the major neurotransmitters have also been identified, e.g. the synaptosomal-associated protein 25 gene (Gizer et al. 2009). New findings from genome-wide association studies provide additional support for common effects of genes coding for cell adhesion molecules (e.g., CDH13, ASTN2) and regulators of synaptic plasticity (e.g. CTNNA2) (Lesch et al. 2008).

Even though many associations between candidate genes and ADHD have failed despite a plausible aetiological relevance (Gizer et al. 2009), a combination of several genes is likely to be involved in ADHD.

Functional and structural abnormalities

There is a striking similarity in symptoms between patients with lesions in the prefrontal cortex (PFC) and individuals with ADHD (Benton 1991; Heilman et al. 1991; Levin
1938; Mattes 1980), which suggests an important role of the PFC in ADHD. Three studies using magnetic resonance imaging (MRI) found a decreased volume of the right PFC in children with ADHD, while no such result was found regarding the left PFC (Castellanos et al. 1996b; Filipek et al. 1997; Hynd et al. 1990). Other brain nuclei including the basal ganglia were also found to be altered. For example, two studies described a reduced volume of the left caudate nucleus in children with ADHD (Filipek et al. 1997; Hynd et al. 1993). Two further studies found a reduced volume of the globus pallidus in children with ADHD compared to normal controls (Aylward et al. 1996; Castellanos et al. 1996b). However, whereas Castellanos et al. (1996b) observed a volume reduction in the right pallidum, Aylward et al. (1996) found a smaller left pallidum. Even more important is the observation that the size of the basal ganglia and the right frontal lobe appears to correlate with the degree of impairment in attention and inhibition in children with ADHD (Casey et al. 1997; Semrud-Clikeman et al. 2000).

The volumes of several regions of the corpus callosum, such as the anterior genu (Hynd et al. 1991), rostral body regions (Baumgardner et al. 1996; Giedd et al. 1994) and splenial regions (Hynd et al. 1991; Semrud-Clikeman et al. 1994) have also been shown to be reduced in ADHD. Other brain regions including the temporal lobe, insula, hippocampus, amygdala or the central grey did not differ between children with ADHD and controls (Castellanos et al. 1996b; Filipek et al. 1997).

Some studies have reported a reduced cerebellar volume, especially concerning the vermis, in children with ADHD (Castellanos et al. 1996b, 2001, 2002; Durston et al. 2004). The meaning of this finding is not entirely clear. Some studies have shown a close connection between the cerebellum and certain parts of the PFC. It has been suggested that there are anatomically separate output channels of the cerebellum to the PFC and back to the pons, which is the main input to the cerebellum (Middleton and Strick 1997a, b, 2001). These data suggest a circuit involved in cognition between the cerebellum and the PFC. Furthermore, based on observations in patients with cerebellar tumours, a cerebellar cognitive affective syndrome was postulated (Schmahmann 2004; Schmahmann and Sherman 1998), which is characterized by deficits in executive functions, disturbed spatial orientation and uninhibited behaviour. All these disturbances can also be observed in ADHD. The cerebellum may therefore play a role in ADHD.

Several single photon emission computed tomography (SPECT) studies have shown a reduced blood flow in prefrontal regions and the connecting pathways to the limbic system and cerebellum (Lou et al. 1984, 1989, 1990; Sieg et al. 1995). Even more interesting is the fact that the 
reduction in blood flow in these regions is reversed by methylphenidate (Langleben et al. 2002; Lou et al. 1984, 1989).

In a PET study, Zametkin et al. (1990) found a reduced glucose metabolism in striatum, thalamus, hippocampus, cingulate regions and most prominently in the premotor and superior PFC. Subsequent studies, however, found no overall alterations in these regions (Ernst et al. 1994; Zametkin et al. 1993). Post-hoc analyses revealed a reduced glucose metabolism in females but not in males with ADHD (Ernst et al. 1994, 1997; Zametkin et al. 1993).

In summary, structural and functional abnormalities have been observed within the prefronto-striato-cerebellar network suggesting an important role of this system in ADHD. Evidence in support of this hypothesis is that children with ADHD show different activation patterns during attention and inhibition tasks within prefrontal regions, basal ganglia and cerebellum (Rubia et al. 1999; Teicher et al. 2000; Vaidya et al. 1998; Yeo et al. 2003).

\section{Neurotransmitters}

Given the important role of catecholamines in ADHD, alterations in the metabolism of these neurotransmitters are to be expected. However, the investigation of urinary levels of the NA metabolite 3-methoxy-4-hydroxyphenylglycol (MHPG) has indicated no differences (Rapoport et al. 1978; Wender et al. 1971) or increased levels in ADHD children compared to control subjects (Shekim et al. 1977, 1979, 1983, 1987).

Oades et al. (1998) found slightly elevated levels of plasma NA and adrenaline in children with ADHD compared to controls. But there are indications that there is no correlation between plasma/urine levels of MHPG or the DA metabolite homovanillic acid (HVA) and the behavioural measures of hyperactivity or aggression. Furthermore, the metabolite levels do not predict the response to stimulant medications (Castellanos et al. 1994, 1996a).

The assessment of peripheral levels of catecholamine metabolites has revealed conflicting results, and there are doubts whether these levels actually reflect the brain neurochemistry in ADHD. A better approach is the measurement of these levels in the central nervous system. A few studies have investigated neurotransmitter metabolites in the cerebrospinal fluid (CSF). For example, Shetty and Chase (1976) found no significant differences in the level of CSF-HVA between hyperactive children and normal controls, while Shaywitz et al. (1977) found reduced CSFHVA levels in children with minimal brain dysfunction. However, none of these studies used children with ADHD according to current diagnostic standards. A more recent study by Kruesi et al. (1990) found no differences in the CSF levels of HVA or MHPG in children with disruptive behaviour, many of whom had ADHD, compared to children with obsessive compulsive behaviour. Although these children were diagnosed with ADHD, they also presented with disruptive behaviour and, in addition, they were compared to children with obsessive compulsive behaviour. It is therefore difficult to describe the neurotransmitter status of ADHD children on the basis of this study.

Other studies have attempted to establish a relationship between stimulant medication and central catecholamine activity. For example, Reimherr et al. (1984) found in adults that methylphenidate responders had lower CSFHVA levels than non-responders. A predictive value of CSF-HVA levels for the responsiveness to methylphenidate was confirmed by Castellanos et al. (1996a) who, however, found that increased levels of HVA predicted a good response to stimulant treatment while low levels were associated with a worsening of some symptoms. This discrepancy might be explained by the fact that Castellanos reported on children and Reimherr on adults.

In summary, the findings regarding the neurochemistry of ADHD are inconsistent. Since heterogeneous patient groups were used, it is difficult to perform reliable comparisons between patients and controls. Furthermore, it is questionable whether the levels of peripheral neurotransmitter metabolites reflect the neurochemical status of patients with ADHD, since neither plasma nor urinary levels of HVA and MHPG correlate with hyperactivity or predict the response to stimulant treatment (Castellanos et al. 1994, 1996a). Neurotransmitter metabolite levels in the CSF provide limited information since they reflect the overall activity of a neurotransmitter. Concurrently occurring regional increases and reductions in transmitter activity might offset each other. The above-mentioned findings clearly underline the contribution of a catecholaminergic dysfunction to ADHD.

In ADHD, there appears to be a functional disturbance within the fronto-striato-cerebellar system affecting the neurotransmitters DA and NA. These disturbances may be associated with genes regulating dopaminergic, noradrenergic and probably serotonergic functions. The exact nature of the neurotransmitter dysfunctions is not clear. Further research is therefore needed in order to elucidate the neurobiological basis of ADHD. In this context, the investigation of animal models may be a useful approach.

\section{Dysfunctional systems in ADHD}

Mefford and Potter (1989) postulated a noradrenergic dysfunction of the locus coeruleus (LC) as one of the earliest models of ADHD. This model was supported by findings in monkeys, which showed that the LC is involved in selective processing of sensory stimuli (Aston-Jones 
et al. 1997), which is partly modulated by alpha 2 -autoreceptors (Simson and Weiss 1987). An increase in noradrenaline (NA) suppresses basal firing and enhances responses to stimuli, i.e. an increase in NA leads to more focused behaviour, while a reduction in NA would increase the response to irrelevant stimuli. In addition, adrenaline is known to inhibit the tonic activity of the LC. A deficit in one of the two systems might therefore disrupt stimulusevoked responding, and this could induce deficits in sustained attention.

In contrast to Mefford and Potter (1989), Pliszka et al. (1996) suggested a dysfunction in two neurotransmitter systems. Studies in humans have shown that attention is distributed in a posterior and anterior system (Posner and Petersen 1990). The posterior system includes the superior parietal cortex, the superior colliculus and the pulvinar nucleus. This system receives a dense innervation from the LC (Holets 1990). NA enhances the signal-to-noise ratio and primes, according to Pliszka et al. (1996), the posterior system to orientate to novel stimuli. Attention then shifts to the anterior system, which is known to control executive functions. It consists of the PFC and the anterior cingulate gyrus. The sensitivity of this system is modulated by DA from the ventral tegmental area (VTA). According to Pliszka et al. (1996), a noradrenergic dysfunction could inhibit the priming of the posterior system and lead to attention deficits. A loss of DA could induce deficits in the anterior system and impair executive functions.

A third model suggested by Arnsten et al. (1996) is based on a dysfunction of the alpha 2 -autoreceptors in the prefrontal cortex (PFC). The PFC inhibits the processing of irrelevant sensory stimuli through connections with the association cortex (Cavada and Goldman-Rakic 1989) and therefore protects on-going tasks from interference (Alexander et al. 1976; Knight et al. 1989). This function is regulated by the LC, since ascending noradrenergic fibres

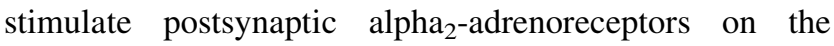
pyramidal cells in the PFC (Aoki et al. 1994) leading to a reduction in spontaneous firing (Hasselmo et al. 1997). Therefore, the activity of the LC primes the PFC to suppress task-irrelevant stimuli and inhibits behaviour. According to Arnsten et al. (1996), a reduced NA activity causes a partial denervation of the alpha 2 receptors in the PFC, thereby disrupting the inhibitory control of children with ADHD. Based on this model, the central deficit in ADHD is a lack of inhibition induced by a decrease in brain NA.

These models differ but they also have certain points in common, e.g. the central role of the PFC and catecholamine neurotransmitters. The models by Mefford and Potter (1989), Pliszka et al. (1996) and Arnsten et al. (1996) emphasize the role of NA in focusing on relevant stimuli or tasks. Pliszka et al. (1996) and Arnsten et al.
(1996) suggest that a reduced noradrenergic activity contributes to attention deficits and distractibility. However, these models need to be tested against findings in patients with ADHD.

\section{Animal models in research}

Animal models of diseases are supposed to show phenomenological similarities with the modelled disease. In animal models of ADHD, one would expect the three core symptoms of this disorder to be present, i.e. attention deficits, hyperactivity and impulsivity (Rhee et al. 1999). These symptom similarities represent the face validity of the model (Willner 1991). However, as Willner (1991) has pointed out, face validity also includes a resemblance regarding aetiology, treatment and the physiological basis of the modelled disease. Most of these aspects cannot be used for validation since they are currently objects of research. Face validity is therefore frequently reduced to symptom similarities. Validity based on symptom similarities alone might be misleading, since not every hyperactive rat is a valid model of ADHD. There may be several alternative reasons why a certain behaviour is observed. The presence of a certain disease symptom does not necessarily reflect the presence of the entire disease. Furthermore, similar behavioural expression does not necessarily indicate that this expression has the same biological substrate. This indicates that models based on symptom similarities alone are weak and that other criteria are needed for the validation of an animal model. Willner (1991) has suggested to check for aspects of construct validity and predictive validity.

Construct validity means that the model conforms to an established or hypothesized pathophysiological basis of the disorder. A disturbance within the fronto-striato-cerebellar system has been postulated in ADHD. An animal showing hyperactivity because of alterations in this system has both construct and face validity. Construct validity is more important than face validity because it is a certain theoretical framework that connects the behavioural symptoms with the modelled disease.

Another criterion used in validating an animal model is predictive validity, which is the ability to predict previously unknown aspects of the genetics, neurobiology and pathophysiology of a disorder or to provide potential new treatments. In practice, drugs with similar effects in human disease and animal model are often used to validate the model.

In summary, the validity of an animal model should not solely be based on behavioural similarities. Both construct and predictive validity have also to be considered. Construct validity depends on the knowledge about the human 
neurobiology of the modelled disease. Since this knowledge is often limited, construct validity is relatively weak.

\section{Animal models of ADHD}

Genetic models (Table 1)

\section{The spontaneously hypertensive rat}

The spontaneously hypertensive rat (SHR) was initially developed as a model of hypertension (Okamoto and Aoki 1963) by inbreeding rats of the Wistar-Kyoto strain (WKY). This rat strain also showed high spontaneous motor activity suggesting it as an animal model of ADHD (Moser et al. 1988). Sagvolden and colleagues established it as one of the best studied animal models of ADHD (Sagvolden et al. 1992, 1998; Sagvolden 2000). The SHR shows several major ADHD symptoms such as impulsivity, learning deficits or a reduced waiting capacity. These findings suggest a good face validity of this model (Moser et al. 1988; Sagvolden 2000; Wyss et al. 1992). The deficits observed are likely to be related to dysfunctioning within the fronto-striatal system. For example, the SHR has an impaired release of DA in the prefrontal cortex, nucleus accumbens and caudate-putamen (Deutch and Roth 1990;
Jones et al. 1995; Myers et al. 1981; Russell et al. 1995, 1998, 2000b; Russell 2000). Young male SHRs have an increased density of $D_{1}$ and $D_{5}$ receptors in the neostriatum and nucleus accumbens (Carey et al. 1998), and a recent study by Li et al. (2007) showed that SHRs show a reduced expression of the $\mathrm{D}_{4}$ receptor gene in the PFC.

In addition, alterations in the noradrenergic system such as elevated concentrations of NA in the LC, substantia nigra and PFC have been found (de Villiers et al. 1995). This finding is in line with an increased NA transmission and a down-regulation of beta-adrenoreceptors (Myers et al. 1981). Glutamatergic-induced NA release in the prefrontal cortex is higher in SHRs than in control WKY rats (Russell and Wiggins 2000), while the stimulusinduced release from prefrontal cortex slices does not differ between these rat strains (Russell et al. 2000a, b). However, the inhibition of NA release by the alpha ${ }_{2}$-autoreceptor may be deficient (Reja et al. 2002; Russell et al. 2000a, b; Tsuda et al. 1990) suggesting an overall increased noradrenergic transmission in SHR. Finally, the behavioural deficits can be attenuated with monoaminergic agents (Boix et al. 1998; Myers et al. 1982). The SHR shows therefore several aspects of face validity, construct validity and predictive validity.

However, hypertension is a confounding factor in this animal model since it is not associated with ADHD, and it

Table 1 Genetic animal models of ADHD

\begin{tabular}{|c|c|c|c|c|c|}
\hline & Modification & Face validity & Predictive validity & Construct validity & $\begin{array}{l}\text { Missing data and problems } \\
\text { with the model }\end{array}$ \\
\hline SHR & $\begin{array}{l}\text { Bred for } \\
\text { hypertension }\end{array}$ & $\begin{array}{l}\text { Hyperactivity, } \\
\text { impulsivity, } \\
\text { learning deficits }\end{array}$ & $\begin{array}{l}\text { All symptoms reduced } \\
\text { by monoaminergic } \\
\text { agents }\end{array}$ & $\begin{array}{l}\text { Dysfunctional fronto- } \\
\text { striatal system }\end{array}$ & $\begin{array}{l}\text { Hypertension, WKY rats as } \\
\text { control group }\end{array}$ \\
\hline DAT-KO & $\begin{array}{l}\text { Knock-out of the } \\
\text { dopamine- } \\
\text { transporter gene }\end{array}$ & $\begin{array}{l}\text { Hyperactivity, } \\
\text { spatial memory } \\
\text { deficits }\end{array}$ & $\begin{array}{l}\text { Hyperactivity reduced } \\
\text { by psychostimulants }\end{array}$ & $\begin{array}{l}\text { Alterations in the } \\
\text { dopaminergic system }\end{array}$ & $\begin{array}{l}\text { No hints for reduced dopamine } \\
\text { transporter in patients with } \\
\text { ADHD }\end{array}$ \\
\hline $\begin{array}{l}\text { Coloboma } \\
\text { mouse }\end{array}$ & $\begin{array}{l}\text { Mutation on the } \\
\text { SNAP-25 gene }\end{array}$ & $\begin{array}{l}\text { Hyperactivity, } \\
\text { impulsivity }\end{array}$ & - & $\begin{array}{l}\text { Alterations in the } \\
\text { dopaminergic and } \\
\text { noradrenergic systems }\end{array}$ & $\begin{array}{l}\text { No data on predictive validity } \\
\text { Role of SNAP- } 25 \text { in ADHD is } \\
\text { unclear }\end{array}$ \\
\hline $\begin{array}{l}\text { Naples high- } \\
\text { excitability } \\
\text { rat }\end{array}$ & Bred for excitability & Hyperactivity & - & $\begin{array}{l}\text { Alterations in the } \\
\text { dopaminergic system }\end{array}$ & $\begin{array}{l}\text { No data on predictive validity } \\
\text { No data on impulsivity }\end{array}$ \\
\hline $\begin{array}{l}\text { Acallosal } \\
\text { mouse }\end{array}$ & $\begin{array}{l}\text { Agenesis of the } \\
\text { corpus callosum }\end{array}$ & $\begin{array}{l}\text { Hyperactivity, } \\
\text { learning deficits }\end{array}$ & - & $\begin{array}{l}\text { Reduced callosal regions } \\
\text { found in patients with } \\
\text { ADHD }\end{array}$ & $\begin{array}{l}\text { Role of the corpus callosum in } \\
\text { ADHD unclear } \\
\text { No data on the dopaminergic } \\
\text { and noradrenergic systems } \\
\text { No data on predictive validity }\end{array}$ \\
\hline $\begin{array}{l}\text { (TR)-beta(1) } \\
\text { transgenic } \\
\text { mouse }\end{array}$ & $\begin{array}{l}\text { Carries a mutant } \\
\text { human TR } \beta 1 \text { gene }\end{array}$ & $\begin{array}{l}\text { Hyperactivity, } \\
\text { impulsivity, } \\
\text { inattention }\end{array}$ & $\begin{array}{l}\text { All symptoms reduced } \\
\text { by methylphenidate }\end{array}$ & $\begin{array}{l}\text { Alterations in the } \\
\text { dopaminergic system }\end{array}$ & $\begin{array}{l}\text { Role of the thyroid system in } \\
\text { ADHD unclear }\end{array}$ \\
\hline $\begin{array}{l}\text { Alpha- } \\
\text { synuclein } \\
\text { lacking } \\
\text { mouse }\end{array}$ & $\begin{array}{l}\text { Lack of alpha and } \\
\text { gamma synuclein }\end{array}$ & $\begin{array}{l}\text { Hyperactivity, } \\
\text { working memory } \\
\text { deficits }\end{array}$ & - & $\begin{array}{l}\text { Increased dopamine } \\
\text { release }\end{array}$ & $\begin{array}{l}\text { No data on predictive validity } \\
\text { No data on attention } \\
\text { No data on impulsivity }\end{array}$ \\
\hline
\end{tabular}


cannot be excluded that increased blood pressure affects behaviour. The behavioural deficits in SHRs might reflect dysfunctioning or brain damage caused by high blood pressure. Some human studies have shown a negative effect of hypertension on cognition (Anstey and Christensen 2000; Birkenhager et al. 2001). Young SHRs do not show hypertension and Diana (2002) reported no cognitive decline in aged SHRs compared to WKY rats. These findings suggest that the cognitive deficits in SHRs do not depend on hypertension. Both SHRs and WKY rats have shown a poor performance at the age of 6 months compared to normal Sprague-Dawley rats. This suggests that both young SHRs and young WKY rats show cognitive impairment, which does not worsen with increasing age. This is in support of the SHR as a model of ADHD. However, the finding that WKY rats have cognitive deficits puts in question the use of these rats as controls for SHRs. Interestingly, Pare (1989) reported a decrease in open field activity in WKY rats compared to Wistar rats and SHRs. These findings were confirmed by other researchers (McCarty and Kirby 1982; Sagvolden et al. 1993; Schaefer et al. 1978). WKY rats have also shown decreased activity levels in the forced swim test suggesting them as a model of depression (Lahmame et al. 1997). It is therefore not surprising that SHRs show increased motor activity when compared to hypoactive rats. In a recent report, Alsop (2007) could not show any difference between SHRs and WKY rats when correcting for different activity levels in these two strains. As Alsop (2007) pointed out, this does not necessarily mean that the SHR is of no use as an animal model of ADHD. However, all studies comparing SHRs with WKY rats have to be interpreted with care.

In summary, the SHR is a well-studied model, and many studies have confirmed the necessary validation criteria. The influence of hypertension and the problematic role of WKY rats as control animals remain unsolved problems.

\section{The dopamine-transporter knockout mouse}

The DA transporter knockout (DAT-KO) mouse lacks the DA transporter (DAT) gene and shows some ADHD symptoms such as spontaneous behavioural hyperactivity (Gainetdinov et al. 1999; Gainetdinov and Caron 2001; Giros et al. 1996) or deficits in spatial memory (Gainetdinov et al. 1999; Gainetdinov and Caron 2001). The hyperactivity observed in DAT-KO mice is associated with a marked decrease in DA clearance (Jones et al. 1998a), which is most likely due to the lack of the DAT. This lack has been shown to induce several compensatory changes such as a decrease in DA release from nerve terminals (Gainetdinov et al. 1998; Jones et al. 1998a) so that the extracellular DA concentration is only increased about fivefold.
The concentration of DA metabolites has been shown to vary. HVA is increased, while 3,4-dihydroxyphenylacetic acid (DOPAC) is unaltered (Jones et al. 1998a). There are also changes on the postsynaptic side such as a decrease in $\mathrm{D}_{1}$ and $\mathrm{D}_{2}$ receptor protein and mRNA in the basal ganglia (Gainetdinov et al. 1998; Jaber et al. 1996, 1999). Paradoxically, hyperactivity can be inhibited by compounds such as amphetamine, methylphenidate and cocaine, which act primarily on the DA transporter (Gainetdinov et al. 1998; Gainetdinov and Caron 2001; Jones et al. 1998b). This suggests that the therapeutic effects of these compounds in ADHD are not necessarily based on changes in dopaminergic transmission alone. In line with this is the finding that the DA concentration in the striatum of DAT-KO mice is not increased after challenges with the psychostimulant drugs in a new environment (Gainetdinov et al. 1998, 1999; Gainetdinov and Caron 2001). Since these agents also act on the noradrenergic system, it is likely that the reduction in hyperactivity in the DAT-KO mouse is based on alterations of the noradrenergic system rather than the dopaminergic system.

In summary, this mouse model shows some face, construct and predictive validity because of behavioural similarities, alterations of the catecholaminergic system and the effectiveness of psychostimulants. However, animal models have to be compared with patients, and there are so far no indications that the DAT is reduced in patients with ADHD. On the contrary, several studies have found increased DAT levels in the striatum of adults and children with ADHD (Cheon et al. 2003; Dougherty et al. 1999; Krause et al. 2000).

\section{The coloboma mutant mouse}

The coloboma mutant mouse was developed using neutron irradiation (Searle 1966). This mouse shows delayed neurodevelopment and behavioural deficits such as motor hyperactivity, impulsivity and impaired inhibition in a delayed reinforcement task (Bruno et al. 2007; Hess et al. 1994, 1996; Heyser et al. 1995; Wilson 2000). The hyperactivity observed could be reduced by D-amphetamine but not by methylphenidate (Hess et al. 1996; Wilson 2000). Since this mouse has a mutation on the SNAP-25 gene, it is likely that the behavioural deficits are related to a SNAP-25 dysfunction (Hess et al. 1992, 1996; Steffensen et al. 1996). The SNAP-25 protein is essential for the fusion of the neurotransmitter vesicle with the presynaptic membrane in order to release neurotransmitters. This might explain why the DA release in the dorsal striatum of the coloboma mutant mouse is almost completely lost (Raber et al. 1997). In addition, the $\mathrm{D}_{2}$ receptor expression is increased in the ventral tegmental area and substantia nigra (Jones et al. 2001b). 
Alterations in the noradrenergic system such as an increased NA concentration in the striatum, LC and nucleus accumbens were also observed (Jones et al. 2001a). NA depletion following the administration of the neurotoxin $N$-(2-chloroethyl)- $N$-ethyl-2-bromobenzylamine (DSP4) has been shown to reduce the hyperactivity but not the impulsivity (Bruno et al. 2007; Jones and Hess 2003). In line with this is the finding that adrenergic receptor antagonists also reduce hyperactivity (Bruno and Hess 2006). Taken together, these results suggest that the motor activity in coloboma mutant mice is related to a hyperactive noradrenergic system.

In summary, the biochemical data suggest that-similar to the SHR - the coloboma mouse has a hyperactive noradrenergic system and a hypoactive dopaminergic system. The alterations of the catecholaminergic systems support the construct validity of this mouse. Face validity is given by the behavioural deficits, and predictive validity is given through the effects of amphetamine. However, the role of the SNAP-25 gene in ADHD remains to be investigated. Hess and colleagues found no link between ADHD and the SNAP-25 gene (Hess et al. 1995) whereas findings from another group suggest a role of SNAP-25 in ADHD (Barr et al. 2000).

\section{The Naples high-excitability rat}

Naples high-excitability (NHE) rats were selected based on an increased exploration behaviour as assessed in the lat-maze. This increased activity is dependent on the environment, e.g. no hyperactivity could be observed in the rats' home cage (Sadile 1993) and motor activity increased with increasing complexity of the environment (Sadile et al. 1993; Viggiano et al. 2002b, 2003b). In addition, NHE rats showed deficits in visual-spatial attention but no deficits in working memory (Aspide et al. 1998; Gallo et al. 2002; Papa et al. 2000). Further investigations have shown that these rats have alterations in the dopaminergic system. For example, tyrosine hydroxylase, DAT and $\mathrm{D}_{2}$ receptor mRNA are hyperexpressed in the PFC, while the $\mathrm{D}_{1}$ receptor is down-regulated. No such changes have been reported for the striatum (Viggiano et al. 2002a, b, 2003a, b; Viggiano and Sadile 2000).

Face validity of this model is supported by the presence of motor hyperactivity and attentional deficits. Construct validity is given because these deficits are probably based on altered dopaminergic function in the forebrain. However, studies regarding impulsivity or the effects of psychostimulants on the deficits observed are still lacking. Therefore, this model has so far no predictive validity.

\section{The acallosal mouse strain}

Acallosal mice show a complete agenesis of the corpus callosum. This mouse strain presents with learning deficits (Lipp et al. 1990; Lipp and Wahlsten 1992; Magara et al. 2000) and signs of hyperactivity, such as a reduced number of brief stops and a decrease in habituation in an open field (Magara et al. 2000). This behaviour appears to be related to a functional dominance of the right hemisphere (Magara et al. 2000). This is interesting since dysfunctioning of the right hemisphere has also been discussed in human ADHD (Garcia-Sanchez et al. 1997; Stefanatos and Wasserstein 2001), and reduced sizes of callosal regions have been found in some patients with ADHD (Baumgardner et al. 1996; Giedd et al. 1994; Hynd et al. 1991; SemrudClikeman et al. 1994). However, whether or not alterations in the human corpus callosum contribute to the aetiology of ADHD remains an open question. In addition, information regarding impulsive behaviour and attentional deficits, possible alterations in the catecholaminergic system and the effects of psychostimulants are still lacking. Taken together, the validity of this model appears to be rather weak.

\section{The thyroid hormone receptor (TR)-beta(1) transgenic mouse}

A relatively new animal model of ADHD is the TR-beta(1) transgenic mouse. This mouse carries a mutant human TR $\beta 1$ gene, which was derived from a patient diagnosed to suffer from a resistance to thyroid hormone (RTH) syndrome. This rare syndrome is heritable and characterized by elevated thyroid hormone levels, normal or elevated levels of thyroid stimulating hormone (TSH), a short stature, hearing loss and tachycardia (Weiss and Refetoff 2000). Even more interesting is the fact that approximately $70 \%$ of children with RTH syndrome meet the diagnostic criteria for ADHD (Burd et al. 2003). This suggests a common mechanism related to the thyroid system in both diseases.

Both patients with the human RTH syndrome and the transgenic mouse show an increased level of thyroid hormone and normal levels of TSH. In comparison with the wild type, the TR-beta(1) transgenic mouse is hyperactive but not impulsive and shows normal attentional functioning (McDonald et al. 1998). However, using another promoter for the TR $\beta 1$ gene, Siesser et al. (2006) were able to induce impulsivity, inattention and hyperactivity in these mice. As shown in patients with ADHD and in most animal models, the locomotor hyperactivity was primarily present in a familiar environment. Furthermore, an elevated DA turnover and the sensitivity to treatment with methylphenidate 
suggest that these behavioural deficits are related to the catecholaminergic system (Siesser et al. 2006).

Thyroid abnormalities are rare in children with ADHD (Weiss et al. 1993). The behavioural deficits in this mouse model were present at adulthood, although elevated levels of TSH were only found around the age of 33 days. These findings suggest that a short period of thyroid abnormalities during brain development might be responsible for the behavioural phenotype of these mice (Siesser et al. 2006). A similar mechanism could be possible in humans, which might explain why thyroid levels are not abnormal in children with ADHD.

In summary, this model shows good face validity because all three core symptoms of ADHD are present. It has predictive validity since these mice are sensitive to the treatment with methylphenidate. Finally, it shows some construct validity because of alterations in the catecholaminergic system and developmental disturbances.

However, the role of the thyroid system in ADHD is not entirely clear. One study has suggested that subclinical maternal thyroid abnormalities may contribute to the development of ADHD (Haddow et al. 1999). Abnormal thyroid hormone levels are known to have severe effects on brain development and cognition (Thompson and Potter 2000). One might therefore assume that alterations in thyroid system induce deficits in brain development resulting in the ADHD behavioural phenotype.

\section{Alpha-synuclein lacking mice}

The synucleins are a family of three proteins (alpha, beta, gamma), which are mainly seen in presynaptic terminals (Nakajo et al. 1993; Totterdell et al. 2004; Totterdell and Meredith 2005). The alpha-synuclein protein has been shown to be involved in the pathogenesis of Parkinson's disease (Chartier-Harlin et al. 2004; Zarranz et al. 2004) suggesting that alpha-synuclein is important in the regulation of DA transmission. In a recent study, Senior et al. (2008) found that mice lacking both alpha- and gammasynuclein proteins showed hyperactive behaviour in a novel environment and a reduced alternate rate in the T-maze spontaneous alternation task. These behaviours are most likely associated with an increase in DA release. Both the hyperactive behaviour and the deficit in working memory show that this model has some face validity for ADHD. The construct validity is given because of the increase in DA release. However, hyperactive behaviour in these mice is only present in a novel environment and the activity in the home cage does not differ to the wild type. It has been suggested that hyperactivity in a familiar environment is a better indicator of ADHD-like hyperactivity (Sagvolden et al. 2005). Furthermore, no data are available with respect to attention deficits or impulsive behaviour.
The validity of this model of ADHD is so far only based on hyperactive behaviour and alterations in the dopaminergic system.

Pharmacological animal models of ADHD (Table 2)

Juvenile rodents with a neonatal 6-hydroxydopamineinduced brain lesion

The experimental destruction of DA-containing neurons with 6-hydroxydopamine (6-OHDA) in adult rats is an established model of Parkinson's disease. Lesions of the dopaminergic system in neonatal rats lead to age-limited spontaneous motor hyperactivity (Creese and Iversen 1973; Heffner and Seiden 1982; Luthman et al. 1989, 1997; Shaywitz et al. 1976a, b). Hyperactivity observed in this rat is most prominent prior to puberty (Erinoff et al. 1979; Shaywitz et al. 1976b; Zhang et al. 2002b) and can be antagonized by stimulants (Davids et al. 2002; Heffner and Seiden 1982; Luthman et al. 1989; Shaywitz et al. 1976a). These deficits disappear in adult rats, probably due to on-going developmental processes. Most behavioural deficits observed are based on acute adaptive alterations in the dopaminergic system due to the 6-OHDA lesion. For example, the remaining dopaminergic neurons release more DA from their terminals (Carder et al. 1989; Castaneda et al. 1990). Both presynaptic $\mathrm{D}_{2}$ autoreceptors and DA transporters are reduced (Joyce et al. 1996; Schwarting and Huston 1996). Further data suggest that increased $\mathrm{D}_{4}$ receptor levels in the caudate-putamen correlate with behavioural hyperactivity (Zhang et al. 2001). Furthermore, the $D_{4}$ receptor seems to be essential for hyperactive behaviour (Avale et al. 2004a). Mice with neonatal 6-OHDA lesions lacking the $\mathrm{D}_{4}$ receptor did not show hyperactive behaviour compared to the wild type (Avale et al. 2004a). This effect was not based on a different sensitivity to 6-OHDA since both genotypes showed an equivalent degree of DA depletion. These findings are important since a polymorphism of the $\mathrm{D}_{4}$ receptor has been linked to ADHD (Faraone et al. 1999; Faraone and Doyle 2001; Grady et al. 2003; LaHoste et al. 1996; Swanson et al. 1998). This model appears therefore to be useful in the investigation of the role of the $\mathrm{D}_{4}$ receptor in ADHD.

The 6-OHDA lesion also affects other neurotransmitter systems. For example, a serotonergic hyperinnervation of the striatum was found (Descarries et al. 1992; Frohna et al. 1997; Kostrzewa et al. 1998; Luthman et al. 1990; Stachowiak et al. 1984; Towle et al. 1989; Zhang et al. 2002a). By contrast, no such changes were observed in the noradrenergic system (Luthman et al. 1990; Ordway 1995). A study by Avale et al. (2004b) suggests that the increase in striatal serotonin is associated with hyperactive behaviour. 
Table 2 Pharmacological animal models of ADHD

\begin{tabular}{|c|c|c|c|c|c|}
\hline & Modification & Face validity & Predictive validity & Construct validity & $\begin{array}{l}\text { Missing data and problems } \\
\text { with the model }\end{array}$ \\
\hline $\begin{array}{l}\text { Neonatal } \\
\text { 6-OHDA- } \\
\text { lesion }\end{array}$ & $\begin{array}{l}\text { Lesion of central } \\
\text { dopaminergic } \\
\text { neurons }\end{array}$ & Hyperactivity & $\begin{array}{l}\text { Hyperactivity reduced } \\
\text { by methylphenidate }\end{array}$ & $\begin{array}{l}\text { Alterations in the } \\
\text { dopaminergic system }\end{array}$ & $\begin{array}{l}\text { No data on impulsivity and } \\
\text { inattention }\end{array}$ \\
\hline $\begin{array}{l}\text { Neonatal } \\
\text { hypoxia }\end{array}$ & $\begin{array}{l}\text { Hypoxia induced by } \\
\text { nitrogen }\end{array}$ & $\begin{array}{l}\text { Hyperactivity, } \\
\text { learning } \\
\text { deficits }\end{array}$ & $\begin{array}{l}\text { Symptoms reduced by } \\
\text { amphetamine }\end{array}$ & $\begin{array}{l}\text { Alterations in the } \\
\text { dopaminergic, } \\
\text { noradrenergic and } \\
\text { serotonergic systems }\end{array}$ & $\begin{array}{l}\text { No data on impulsivity and } \\
\text { inattention- }\end{array}$ \\
\hline $\begin{array}{l}\text { Development } \\
\text { cerebellar } \\
\text { stunting }\end{array}$ & $\begin{array}{l}\text { Lesion of the } \\
\text { cerebellum }\end{array}$ & Hyperactivity & - & $\begin{array}{l}\text { Reduction in cerebellar } \\
\text { volume found in patients } \\
\text { with ADHD }\end{array}$ & $\begin{array}{l}\text { No data on impulsivity, } \\
\text { inattention and cognitive } \\
\text { deficits } \\
\text { No data on alterations of } \\
\text { the dopaminergic and } \\
\text { noradrenergic systems } \\
\text { Hyperactivity increases } \\
\text { with amphetamine }\end{array}$ \\
\hline $\begin{array}{l}\text { Maternally } \\
\text { stressed mice }\end{array}$ & Maternal stress & Hyperactivity & $\begin{array}{l}\text { Hyperactivity reduced } \\
\text { by dopamine } \\
\text { antagonist }\end{array}$ & $\begin{array}{l}\text { Correlation between } \\
\text { perinatal stress and } \\
\text { ADHD }\end{array}$ & $\begin{array}{l}\text { No data on impulsivity, } \\
\text { inattention and cognitive } \\
\text { deficits }\end{array}$ \\
\hline
\end{tabular}

Avale and colleagues treated mice with neonatal 6-OHDA lesions with a tryptophan hydroxylase inhibitor in order to normalize striatal serotonin without affecting DA levels. These mice did not show hyperactive behaviour.

In summary, this model shows some predictive validity, since treatment with psychostimulants reduces the hyperactivity. Construct validity is given by the profound changes in the catecholaminergic neurotransmitter system. Finally, the hyperactivity of this model supports face validity. In addition, this model enables the study of the role of the $\mathrm{D}_{4}$ receptor and serotonin in ADHD. However, data regarding impulsive behaviour or specific attentional deficits are not available.

\section{Neonatal hypoxia in rats}

Hypoxia induced by nitrogen after birth has been shown to induce ADHD-like behavioural deficits (Dell'Anna et al. 1993; Speiser et al. 1983, 1988) including age-limited hyperactivity and deficits in learning and memory (Gramatte and Schmidt 1986). The hyperactivity can be counteracted with D-amphetamine (Speiser et al. 1983). As shown following neonatal lesions, hypoxia induces several adaptive monoaminergic alterations which change with age (Dell'Anna et al. 1993). The acute effect is a decrease in NA in the cortex and of DA in the striatum, while the serotonin metabolite 5-hydroxyindoleacetic acid (5-HIAA) is increased in both cortex and cerebellum (Dell'Anna et al. 1993). A week after hypoxia NA was increased in the cerebellum, and serotonin and 5-HIAA were decreased in both cerebellum and cortex. On postnatal day 21, NA in the hippocampus and HVA in the striatum were increased. By contrast, serotonin was decreased in the striatum with increased levels of its metabolite 5-HIAA in striatum and hippocampus. Finally, on postnatal day 60, DOPAC and 5-HIAA levels were increased in the striatum (Dell'Anna et al. 1993).

The learning deficits reported might be related to morphological changes in the hippocampus since neuronal density was reduced in the CA1 region starting on postnatal day 15 , and indexes of neuronal repair could be observed on postnatal day 7 (Dell'Anna et al. 1995).

It still remains to be established to what extent these complex changes contribute to ADHD.

In summary, face validity of this model is based on hyperactivity, while studies investigating attention deficits or impulsivity are missing. The alterations in the catecholaminergic system might have some construct validity. However, it remains unclear whether these complex changes reflect the symptoms of ADHD. Some predictive validity is given by the effect of D-amphetamine on hyperactivity.

\section{Developmental cerebellar stunting in rats}

A significantly reduced cerebellar volume in children with ADHD has been reported (Castellanos et al. 1996b, 2001, 2002; Durston et al. 2004), suggesting a role of the cerebellum in ADHD. Animal models using lesions of the cerebellum may therefore show some construct validity.

Various substances have been used for cerebellar lesions. For example, the administration of metylazoxymethanol (MAM) before postnatal day 4 resulted in hyperactivity while treatment from postnatal day 4 onwards resulted in 
mild hyperactivity (Ferguson et al. 1996; Ferguson 1996, 2001). However, the treatment with amphetamine increased the activity (Ferguson et al. 1996). The administration of alpha-difluoromethylornithine (DFMO) on postnatal days 5-10 reduced cerebellar brain volume and affected cerebellar development but did not change open field behaviour (Cada et al. 2000). The administration of dexamethason in rats on postnatal day 7 has been shown to cause decreased cerebellar volume and mild hyperactivity in an open field (Ferguson and Holson 1999).

With regard to ADHD, lesions performed between postnatal days 5 and 12 show some face validity because of the hyperactivity observed. However, amphetamine treatment increased the hyperactivity indicating that evidence of predictive validity is missing. The criterion of construct validity is difficult to judge since data on abnormal catecholamine neurotransmitters are not available. Reductions in cerebellar volume have been found in patients with ADHD. However, it is not clear to what extent the cerebellum contributes to ADHD. Studies in primates have shown a complex circuitry between cerebellum, basal ganglia, PFC and pons (Middleton and Strick 1997a, b, 2001) Therefore, from an anatomical point of view, it is possible that the cerebellum influences PFC activity. In addition, Schmahmann and Sherman (1998) and Schmahmann (2004) have postulated a cerebellar cognitive affective syndrome, which has some behavioural similarities with ADHD. In summary, this model may have potential to study the role of the cerebellum in ADHD. However, the data available at present are not sufficient to describe cerebellar stunting as a valid model of ADHD.

\section{Maternally stressed mice}

A recent study by Son et al. (2007) has suggested the use of maternally stressed adult mice as an animal model of ADHD. It was found that the adult offspring of mice treated with restraint stress during pregnancy were hyperactive. These mice showed a reduced habituation to a novel environment compared to control mice. Furthermore, wheel-running activity was still increased in these mice after three days of habituation. The use of a DA antagonist reduced the wheel-running activity to the level of the control mice, suggesting that the hyperactive behaviour is associated with DA. The maternally stressed adult mice also showed a reduced expression of the DAT and an increased DA turnover in the striatum.

The maternally stressed adult mice have face validity because of their hyperactive behaviour. Construct validity is given because of the alteration in the dopaminergic system. Furthermore, there are studies in humans suggesting a correlation between stress during pregnancy and the onset of ADHD (Laucht et al. 2000; McIntosh et al.
1995). However, further studies investigating attention, impulsivity and cognitive deficits are necessary to validate this model.

\section{Discussion}

Although ADHD is a common disorder among children and adolescents, little is known about its neurobiological basis. It has been suggested that disturbances within the fronto-striatal system and altered levels of the neurotransmitters DA and NA are involved in the pathophysiology of ADHD. This is based on several indications. For example, patients with prefrontal lesions show behavioural similarities with ADHD patients (Benton 1991; Heilman et al. 1991; Levin 1938; Mattes 1980) and the right PFC volume is reduced in children with ADHD (Castellanos et al. 1996b; Filipek et al. 1997; Hynd et al. 1990). Both basal ganglia and frontal lobe volumes correlate with impaired attention and inhibition (Casey et al. 1997; SemrudClikeman et al. 2000). Finally, methylphenidate increases the reduced blood flow in prefrontal regions of individuals with ADHD (Langleben et al. 2002; Lou et al. 1984, 1989). DA and NA are important neurotransmitters in these brain regions, and a dysfunction of these neurotransmitters appears to be likely. This is also underlined by the fact that treatment with psychostimulants reduces ADHD symptoms.

Different pathophysiological mechanisms have been suggested on the basis of altered dopaminergic and noradrenergic neurotransmission. For example, Arnsten et al. (1996) have suggested a sole reduction in noradrenergic function while Pliszka et al. (1996) postulated a combination of dopaminergic hypofunctioning and noradrenergic dysfunctioning as the basis of the core symptoms of ADHD. Studies investigating neurotransmitter levels in patients revealed conflicting results. Some studies found indications of an altered activity in catecholaminergic metabolites (Oades et al. 1998; Shaywitz et al. 1977; Shekim et al. 1977, 1979, 1983, 1987), while others found no differences (Rapoport et al. 1978; Shetty and Chase 1976; Wender et al. 1971). However, it has to be considered that the patients investigated in these studies differed with regard to comorbidity, medication and other relevant factors. Catecholamine metabolites may not reflect the neurochemical status of patients with ADHD since neither plasma nor urinary levels of HVA and MHPG correlate with hyperactivity or predict the response to stimulant treatment (Castellanos et al. 1994, 1996a).

Given the high heritability of ADHD (Gilger et al. 1992; Rhee et al. 1999), the investigation of genes involved in catecholamine functioning is another research strategy. Recent studies have suggested that both the DAT gene and 
the $\mathrm{D}_{4}$ receptor gene are associated with ADHD (Bobb et al. 2005; DiMaio et al. 2003). However, several studies were not able to establish any association (Bakker et al. 2005; Frank et al. 2004; Langley et al. 2004; Mill et al. 2004).

Although the available data clearly indicate that dopaminergic, noradrenergic and probably serotonergic activities within the fronto-striatal system play an important role in ADHD, there is no prevailing concept of the neurobiology of ADHD. This might reflect the heterogeneous nature of ADHD, and it may not be reasonable to expect a unique biological profile in ADHD.

Further knowledge about the neurobiology of ADHD may be provided by animal models. However, these models will provide reasonable conclusions only if certain validation criteria are fulfilled.

Several animal models of ADHD have been proposed (for review see also Kostrzewa et al. 2008; Russell et al. 2005; Sagvolden et al. 2005; van der Kooij and Glennon 2007), and most of these models were initially based on the presence of hyperactivity. However, face validity of an animal model of ADHD should also include impulsive behaviour and attention deficits. In addition, deficits in learning or executive functions might also be indicators of face validity. Investigations concerning impulsivity and attention deficits are still missing for some of the ADHD models including the acallosal mouse, the neonatal 6-OHDA lesion model, the neonatal hypoxia model, the NHE rat, the DAT-KO mouse and the developmental cerebellar stunting model. Further research is therefore needed in order to validate these models regarding face validity. Most of these models have predictive validity since treatment with psychostimulants reduces hyperactivity. It has sometimes been argued that good predictive validity is given only if both amphetamine and methylphenidate are effective in these models. However, the fact that there are responders and non-responders to methylphenidate among patients with ADHD suggests different types of pathophysiology in ADHD. Differential response to amphetamine and methylphenidate in animal models might therefore reflect different pathophysiological mechanisms. Data concerning predictive validity are not available for the acallosal mouse and the NHE rat, while the treatment of the developmental cerebellar stunting rat with amphetamine leads to an increase in hyperactivity.

With regard to construct validity, alterations in dopaminergic or noradrenergic activities have been reported for all models except the acallosal mouse and developmental cerebellar stunting. The validity of these two models of ADHD is therefore limited. However, the developmental cerebellar stunting rat might have some potential as an animal model, since human studies have suggested a role of the cerebellum in ADHD. Not all models fulfil therefore the criteria necessary. The SHR is the best studied animal model with regard to validity. However, the hypertension in this rat and the use of the WKY rat as control in most studies put in question the use of SHRs as an animal model of ADHD.

Even if all criteria are fulfilled, the models show differences. For example, the SHR shows an impaired DA release, and both neonatal 6-OHDA-lesion rat and coloboma mouse have a decreased DA transmission while the DAT-KO mouse shows an increased DA transmission. Nevertheless, all these animals present with symptoms of ADHD, namely hyperactivity. Both increased and decreased dopaminergic activity can therefore lead to ADHD-like symptoms. This suggests that a dysbalance between presynaptic and postsynaptic activities might be important. There is a similar problem with noradrenergic activity in these models. Pliszka et al. (1996) and Arnsten et al. (1996) have postulated a decreased noradrenergic function in ADHD. Depletion of NA in neonatal rats by administering 6-OHDA in combination with a selective DAT-inhibitor (Teicher et al. 1986) has been shown to induce motor hyperactivity (Raskin et al. 1983), learning deficits (Roberts et al. 1976) and attention deficits (Carli et al. 1983). The main source of central NA is the LC, which innervates the entire cerebral cortex, various subcortical areas, cerebellum and spinal cord. The LC has been found to play an important role in attention, arousal, orientation and vigilance (Solanto 1998) since its neurons selectively respond to target stimuli. Tonic LC activity corresponds with the arousal state, and both very low and very high LC activities are associated with impaired vigilance (Arnsten 1997; Aston-Jones et al. 1994). However, the above-mentioned animal models show either unaltered noradrenergic functioning or an increase in NA functions, while none of the models show a decrease in noradrenergic activity.

Based on the SHR model, one might conclude that increased noradrenergic activity and decreased dopaminergic activity represent the characteristic dysbalance of catecholamines in ADHD. However, there are indications that the opposite might also be true, i.e. both increased and decreased dopaminergic activity can lead to ADHD-like symptoms. The same appears to hold true for noradrenergic activity. Furthermore, the increase in noradrenergic activity in the SHR is closely connected to hypertension, which is one of the most confounding factors in this animal model.

The question therefore arises, which model best represents the nature of ADHD. So far, studies with patients have only shown that the structural alterations in the fronto-striatal-cerebellar system, functional alterations in catecholaminergic systems and genes coding for the DAT and the $\mathrm{D}_{4}$-receptor are associated with ADHD. In regard to construct validity in ADHD animal models, this means that every animal with alterations in these systems has 
some construct validity for ADHD. Therefore, it is the combination of face, predictive and construct validity that makes an animal model more or less valid. This illustrates the basic problem in validating animal models: the more is known about the biology of a disease the more conclusive is the comparison between animal model and modelled disease. However, it is the lack of information that makes it necessary to develop a model in order to learn more about the biology of the modelled disease.

\section{Conclusion}

There are several animal models of ADHD and some of them fulfil all criteria necessary for a valid model. The currently proposed models are heterogeneous with regard to their pathophysiological alterations and their ability to mimic behavioural symptoms and to predict response to medication. This might reflect the heterogeneous nature of ADHD. Since our knowledge about the neurobiology of ADHD from human studies is limited, one cannot at present decide, which model best represents ADHD or certain ADHD subtypes. Animal models with good face and predictive validity may be useful for investigations of the underlying biological substrates of ADHD. At present, the models in use should be described as animal models of ADHD-like symptoms rather than models of ADHD.

Open Access This article is distributed under the terms of the Creative Commons Attribution Noncommercial License which permits any noncommercial use, distribution, and reproduction in any medium, provided the original author(s) and source are credited.

\section{References}

Alexander GE, Newman JD, Symmes D (1976) Convergence of prefrontal and acoustic inputs upon neurons in the superior temporal gyrus of the awake squirrel monkey. Brain Res 116:334-338

Alsop B (2007) Problems with spontaneously hypertensive rats (SHR) as a model of attention-deficit/hyperactivity disorder (AD/HD). J Neurosci Methods 162:42-48

American Psychiatric Association CoNaS (1994) Diagnostic and statistical manual of mental disorders, 4th edn. American Psychatric Association, Washington, DC

Anstey K, Christensen H (2000) Education, activity, health, blood pressure and apolipoprotein $\mathrm{E}$ as predictors of cognitive change in old age: a review. Gerontology 46:163-177

Aoki C, Go CG, Venkatesan C, Kurose H (1994) Perikaryal and synaptic localization of alpha 2A-adrenergic receptor-like immunoreactivity. Brain Res 650:181-204

Arnsten AF (1997) Catecholamine regulation of the prefrontal cortex. J Psychopharmacol 11:151-162

Arnsten AF, Steere JC, Hunt RD (1996) The contribution of alpha 2-noradrenergic mechanisms of prefrontal cortical cognitive function. Potential significance for attention-deficit hyperactivity disorder. Arch Gen Psychiatry 53:448-455
Aspide R, Gironi Carnevale UA, Sergeant JA, Sadile AG (1998) Nonselective attention and nitric oxide in putative animal models of Attention-Deficit Hyperactivity Disorder. Behav Brain Res 95:123-133

Aston-Jones G, Rajkowski J, Kubiak P, Alexinsky T (1994) Locus coeruleus neurons in monkey are selectively activated by attended cues in a vigilance task. J Neurosci 14:4467-4480

Aston-Jones G, Rajkowski J, Kubiak P (1997) Conditioned responses of monkey locus coeruleus neurons anticipate acquisition of discriminative behavior in a vigilance task. Neuroscience 80:697-715

Avale ME, Falzone TL, Gelman DM, Low MJ, Grandy DK, Rubinstein M (2004a) The dopamine D4 receptor is essential for hyperactivity and impaired behavioral inhibition in a mouse model of attention deficit/hyperactivity disorder. Mol Psychiatry 9:718-726

Avale ME, Nemirovsky SI, Raisman-Vozari R, Rubinstein M (2004b) Elevated serotonin is involved in hyperactivity but not in the paradoxical effect of amphetamine in mice neonatally lesioned with 6-hydroxydopamine. J Neurosci Res 78:289-296

Aylward EH, Codori AM, Barta PE, Pearlson GD, Harris GJ, Brandt J (1996) Basal ganglia volume and proximity to onset in presymptomatic Huntington disease. Arch Neurol 53:1293-1296

Bakker SC, van der Meulen EM, Oteman N, Schelleman H, Pearson PL, Buitelaar JK, Sinke RJ (2005) DAT1, DRD4, and DRD5 polymorphisms are not associated with ADHD in Dutch families. Am J Med Genet B Neuropsychiatr Genet 132B:50-52

Barr CL, Feng Y, Wigg K, Bloom S, Roberts W, Malone M, Schachar R, Tannock R, Kennedy JL (2000) Identification of DNA variants in the SNAP-25 gene and linkage study of these polymorphisms and attention-deficit hyperactivity disorder. Mol Psychiatry 5:405-409

Barr CL, Feng Y, Wigg KG, Schachar R, Tannock R, Roberts W, Malone M, Kennedy JL (2001) 5'-untranslated region of the dopamine D4 receptor gene and attention-deficit hyperactivity disorder. Am J Med Genet 105:84-90

Barr CL, Kroft J, Feng Y, Wigg K, Roberts W, Malone M, Ickowicz A, Schachar R, Tannock R, Kennedy JL (2002) The norepinephrine transporter gene and attention-deficit hyperactivity disorder. Am J Med Genet 114:255-259

Baumgardner TL, Singer HS, Denckla MB, Rubin MA, Abrams MT, Colli MJ, Reiss AL (1996) Corpus callosum morphology in children with Tourette syndrome and attention deficit hyperactivity disorder. Neurology 47:477-482

Benton A (1991) Prefrontal injury and behavior in children. Dev Neuropsychol 7:275-282

Biederman J, Newcorn J, Sprich S (1991) Comorbidity of attention deficit hyperactivity disorder with conduct, depressive, anxiety, and other disorders. Am J Psychiatry 148:564-577

Biederman J, Faraone SV, Keenan K, Benjamin J, Krifcher B, Moore C, Sprich-Buckminster S, Ugaglia K, Jellinek MS, Steingard R (1992) Further evidence for family-genetic risk factors in attention deficit hyperactivity disorder. Patterns of comorbidity in probands and relatives psychiatrically and pediatrically referred samples. Arch Gen Psychiatry 49:728-738

Biederman J, Faraone SV, Mick E, Spencer T, Wilens T, Kiely K, Guite J, Ablon JS, Reed E, Warburton R (1995) High risk for attention deficit hyperactivity disorder among children of parents with childhood onset of the disorder: a pilot study. Am J Psychiatry 152:431-435

Birkenhager WH, Forette F, Seux ML, Wang JG, Staessen JA (2001) Blood pressure, cognitive functions, and prevention of dementias in older patients with hypertension. Arch Intern Med 161:152156

Blum K, Cull JG, Braverman ER, Comings DE (1996) Reward deficiency syndrom. Am Sci 84:132-145 
Bobb AJ, Castellanos FX, Addington AM, Rapoport JL (2005) Molecular genetic studies of ADHD: 1991 to 2004. Am J Med Genet B Neuropsychiatr Genet 132B:109-125

Boix F, Qiao SW, Kolpus T, Sagvolden T (1998) Chronic L-deprenyl treatment alters brain monoamine levels and reduces impulsiveness in an animal model of Attention-Deficit/Hyperactivity Disorder. Behav Brain Res 94:153-162

Bradley C (1937) The behaviour of children receiving benzedrine. Am J Psychiatry 94:577-585

Bruno KJ, Hess EJ (2006) The alpha(2C)-adrenergic receptor mediates hyperactivity of coloboma mice, a model of attention deficit hyperactivity disorder. Neurobiol Dis 23:679-688

Bruno KJ, Freet CS, Twining RC, Egami K, Grigson PS, Hess EJ (2007) Abnormal latent inhibition and impulsivity in coloboma mice, a model of ADHD. Neurobiol Dis 25:206-216

Burd L, Klug MG, Coumbe MJ, Kerbeshian J (2003) Children and adolescents with attention deficit-hyperactivity disorder: 1. Prevalence and cost of care. J Child Neurol 18:555-561

Cada AM, Gray EP, Ferguson SA (2000) Minimal behavioral effects from developmental cerebellar stunting in young rats induced by postnatal treatment with alpha-difluoromethylornithine. Neurotoxicol Teratol 22:415-420

Carder RK, Jackson D, Morris HJ, Lund RD, Zigmond MJ (1989) Dopamine released from mesencephalic transplants restores modulation of striatal acetylcholine release after neonatal 6-hydroxydopamine: an in vitro analysis. Exp Neurol 105:251-259

Carey MP, Diewald LM, Esposito FJ, Pellicano MP, Gironi Carnevale UA, Sergeant JA, Papa M, Sadile AG (1998) Differential distribution, affinity and plasticity of dopamine D-1 and D-2 receptors in the target sites of the mesolimbic system in an animal model of ADHD. Behav Brain Res 94:173-185

Carli M, Robbins TW, Evenden JL, Everitt BJ (1983) Effects of lesions to ascending noradrenergic neurones on performance of a 5-choice serial reaction task in rats; implications for theories of dorsal noradrenergic bundle function based on selective attention and arousal. Behav Brain Res 9:361-380

Casey BJ, Castellanos FX, Giedd JN, Marsh WL, Hamburger SD, Schubert AB, Vauss YC, Vaituzis AC, Dickstein DP, Sarfatti SE, Rapoport JL (1997) Implication of right frontostriatal circuitry in response inhibition and attention-deficit/hyperactivity disorder. J Am Acad Child Adolesc Psychiatry 36:374-383

Castaneda E, Whishaw IQ, Lermer L, Robinson TE (1990) Dopamine depletion in neonatal rats: effects on behavior and striatal dopamine release assessed by intracerebral microdialysis during adulthood. Brain Res 508:30-39

Castellanos FX, Elia J, Kruesi MJ, Gulotta CS, Mefford IN, Potter WZ, Ritchie GF, Rapoport JL (1994) Cerebrospinal fluid monoamine metabolites in boys with attention-deficit hyperactivity disorder. Psychiatry Res 52:305-316

Castellanos FX, Elia J, Kruesi MJ, Marsh WL, Gulotta CS, Potter WZ, Ritchie GF, Hamburger SD, Rapoport JL (1996a) Cerebrospinal fluid homovanillic acid predicts behavioral response to stimulants in 45 boys with attention deficit/hyperactivity disorder. Neuropsychopharmacology 14:125-137

Castellanos FX, Giedd JN, Marsh WL, Hamburger SD, Vaituzis AC, Dickstein DP, Sarfatti SE, Vauss YC, Snell JW, Lange N, Kaysen D, Krain AL, Ritchie GF, Rajapakse JC, Rapoport JL (1996b) Quantitative brain magnetic resonance imaging in attention-deficit hyperactivity disorder. Arch Gen Psychiatry 53:607-616

Castellanos FX, Giedd JN, Berquin PC, Walter JM, Sharp W, Tran T, Vaituzis AC, Blumenthal JD, Nelson J, Bastain TM, Zijdenbos A, Evans AC, Rapoport JL (2001) Quantitative brain magnetic resonance imaging in girls with attention-deficit/hyperactivity disorder. Arch Gen Psychiatry 58:289-295
Castellanos FX, Lee PP, Sharp W, Jeffries NO, Greenstein DK, Clasen LS, Blumenthal JD, James RS, Ebens CL, Walter JM, Zijdenbos A, Evans AC, Giedd JN, Rapoport JL (2002) Developmental trajectories of brain volume abnormalities in children and adolescents with attention-deficit/hyperactivity disorder. JAMA 288:1740-1748

Cavada C, Goldman-Rakic PS (1989) Posterior parietal cortex in rhesus monkey: II. Evidence for segregated corticocortical networks linking sensory and limbic areas with the frontal lobe. J Comp Neurol 287:422-445

Chartier-Harlin MC, Kachergus J, Roumier C, Mouroux V, Douay X, Lincoln S, Levecque C, Larvor L, Andrieux J, Hulihan M, Waucquier N, Defebvre L, Amouyel P, Farrer M, Destee A (2004) Alpha-synuclein locus duplication as a cause of familial Parkinson's disease. Lancet 364:1167-1169

Cheon KA, Ryu YH, Kim YK, Namkoong K, Kim CH, Lee JD (2003) Dopamine transporter density in the basal ganglia assessed with [123I]IPT SPET in children with attention deficit hyperactivity disorder. Eur J Nucl Med Mol Imaging 30:306-311

Comings DE, Comings BG, Muhleman D, Dietz G, Shahbahrami B, Tast D, Knell E, Kocsis P, Baumgarten R, Kovacs BW (1991) The dopamine D2 receptor locus as a modifying gene in neuropsychiatric disorders. JAMA 266:1793-1800

Cook EH Jr, Stein MA, Krasowski MD, Cox NJ, Olkon DM, Kieffer JE, Leventhal BL (1995) Association of attention-deficit disorder and the dopamine transporter gene. Am J Hum Genet 56:993-998

Creese I, Iversen SD (1973) Blockage of amphetamine induced motor stimulation and stereotypy in the adult rat following neonatal treatment with 6-hydroxydopamine. Brain Res 55:369-382

Daly G, Hawi Z, Fitzgerald M, Gill M (1999) Mapping susceptibility loci in attention deficit hyperactivity disorder: preferential transmission of parental alleles at DAT1, DBH and DRD5 to affected children. Mol Psychiatry 4:192-196

Davids E, Zhang K, Tarazi FI, Baldessarini RJ (2002) Stereoselective effects of methylphenidate on motor hyperactivity in juvenile rats induced by neonatal 6-hydroxydopamine lesioning. Psychopharmacology (Berl) 160:92-98

de Villiers AS, Russell VA, Sagvolden T, Searson A, Jaffer A, Taljaard JJ (1995) Alpha 2-adrenoceptor mediated inhibition of [3H]dopamine release from nucleus accumbens slices and monoamine levels in a rat model for attention-deficit hyperactivity disorder. Neurochem Res 20:427-433

Dell'Anna ME, Luthman J, Lindqvist E, Olson L (1993) Development of monoamine systems after neonatal anoxia in rats. Brain Res Bull 32:159-170

Dell'Anna ME, Geloso MC, Draisci G, Luthman J (1995) Transient changes in Fos and GFAP immunoreactivity precede neuronal loss in the rat hippocampus following neonatal anoxia. Exp Neurol 131:144-156

Descarries L, Soghomonian JJ, Garcia S, Doucet G, Bruno JP (1992) Ultrastructural analysis of the serotonin hyperinnervation in adult rat neostriatum following neonatal dopamine denervation with 6-hydroxydopamine. Brain Res 569:1-13

Deutch AY, Roth RH (1990) The determinants of stress-induced activation of the prefrontal cortical dopamine system. Prog Brain Res 85:367-402

Diana G (2002) Does hypertension alone lead to cognitive decline in spontaneously hypertensive rats? Behav Brain Res 134:113-121

DiMaio S, Grizenko N, Joober R (2003) Dopamine genes and attention-deficit hyperactivity disorder: a review. J Psychiatry Neurosci 28:27-38

Dougherty DD, Bonab AA, Spencer TJ, Rauch SL, Madras BK, Fischman AJ (1999) Dopamine transporter density in patients with attention deficit hyperactivity disorder. Lancet 354:21322133 
Durston S, Hulshoff Pol HE, Schnack HG, Buitelaar JK, Steenhuis MP, Minderaa RB, Kahn RS, van Engeland H (2004) Magnetic resonance imaging of boys with attention-deficit/hyperactivity disorder and their unaffected siblings. J Am Acad Child Adolesc Psychiatry 43:332-340

Erinoff L, MacPhail RC, Heller A, Seiden LS (1979) Age-dependent effects of 6-hydroxydopamine on locomotor activity in the rat. Brain Res 164:195-205

Ernst M, Liebenauer LL, King AC, Fitzgerald GA, Cohen RM, Zametkin AJ (1994) Reduced brain metabolism in hyperactive girls. J Am Acad Child Adolesc Psychiatry 33:858-868

Ernst M, Cohen RM, Liebenauer LL, Jons PH, Zametkin AJ (1997) Cerebral glucose metabolism in adolescent girls with attentiondeficit/hyperactivity disorder. J Am Acad Child Adolesc Psychiatry 36:1399-1406

Faraone SV, Doyle AE (2001) The nature and heritability of attention-deficit/hyperactivity disorder. Child Adolesc Psychiatr Clin N Am 10:299-316

Faraone SV, Biederman J, Weiffenbach B, Keith T, Chu MP, Weaver A, Spencer TJ, Wilens TE, Frazier J, Cleves M, Sakai J (1999) Dopamine D4 gene 7-repeat allele and attention deficit hyperactivity disorder. Am J Psychiatry 156:768-770

Faraone SV, Perlis RH, Doyle AE, Smoller JW, Goralnick JJ, Holmgren MA, Sklar P (2005) Molecular genetics of attentiondeficit/hyperactivity disorder. Biol Psychiatry 57:1313-1323

Ferguson SA (1996) Neuroanatomical and functional alterations resulting from early postnatal cerebellar insults in rodents. Pharmacol Biochem Behav 55:663-671

Ferguson SA (2001) A review of rodent models of ADHD. In: Solanto MV, Arnsten AFT, Castellanos FX (eds) Stimulant drugs and ADHD, basic and clinical neuroscience. University Press Oxford, Oxford, pp 209-220

Ferguson SA, Holson RR (1999) Neonatal dexamethasone on day 7 causes mild hyperactivity and cerebellar stunting. Neurotoxicol Teratol 21:71-76

Ferguson SA, Paule MG, Holson RR (1996) Functional effects of methylazoxymethanol-induced cerebellar hypoplasia in rats. Neurotoxicol Teratol 18:529-537

Filipek PA, Semrud-Clikeman M, Steingard RJ, Renshaw PF, Kennedy DN, Biederman J (1997) Volumetric MRI analysis comparing subjects having attention-deficit hyperactivity disorder with normal controls. Neurology 48:589-601

Fisher SE, Francks C, McCracken JT, McGough JJ, Marlow AJ, MacPhie IL, Newbury DF, Crawford LR, Palmer CG, Woodward JA, Del'Homme M, Cantwell DP, Nelson SF, Monaco AP, Smalley SL (2002) A genomewide scan for loci involved in attention-deficit/hyperactivity disorder. Am J Hum Genet 70:1183-1196

Floresco SB, Tse MT (2007) Dopaminergic regulation of inhibitory and excitatory transmission in the basolateral amygdalaprefrontal cortical pathway. J Neurosci 27:2045-2057

Frank Y, Pergolizzi RG, Perilla MJ (2004) Dopamine D4 receptor gene and attention deficit hyperactivity disorder. Pediatr Neurol 31:345-348

Franke B, Neale BM, Faraone SV (2009) Genome-wide association studies in ADHD. Hum Genet 126:13-50

Frohna PA, Neal-Beliveau BS, Joyce JN (1997) Delayed plasticity of the mesolimbic dopamine system following neonatal 6-OHDA lesions. Synapse 25:293-305

Gainetdinov RR, Caron MG (2001) Genetics of childhood disorders: XXIV. ADHD, part 8: hyperdopaminergic mice as an animal model of ADHD. J Am Acad Child Adolesc Psychiatry 40:380382

Gainetdinov RR, Jones SR, Fumagalli F, Wightman RM, Caron MG (1998) Re-evaluation of the role of the dopamine transporter in dopamine system homeostasis. Brain Res Brain Res Rev $26: 148-153$

Gainetdinov RR, Wetsel WC, Jones SR, Levin ED, Jaber M, Caron MG (1999) Role of serotonin in the paradoxical calming effect of psychostimulants on hyperactivity. Science 283:397-401

Gallo A, Gonzalez-Lima F, Sadile AG (2002) Impaired metabolic capacity in the perirhinal and posterior parietal cortex lead to dissociation between attentional, motivational and spatial components of exploration in the Naples high-excitability rat. Behav Brain Res 130:133-140

Garcia-Sanchez C, Estevez-Gonzalez A, Suarez-Romero E, Junque C (1997) Right hemisphere dysfunction in subjects with attentiondeficit disorder with and without hyperactivity. J Child Neurol 12:107-115

Gelernter J, O’Malley S, Risch N, Kranzler HR, Krystal J, Merikangas K, Kennedy JL, Kidd KK (1991) No association between an allele at the D2 dopamine receptor gene (DRD2) and alcoholism. JAMA 266:1801-1807

Giedd JN, Castellanos FX, Casey BJ, Kozuch P, King AC, Hamburger SD, Rapoport JL (1994) Quantitative morphology of the corpus callosum in attention deficit hyperactivity disorder. Am J Psychiatry 151:665-669

Gilger JW, Pennington BF, DeFries JC (1992) A twin study of the etiology of comorbidity: attention-deficit hyperactivity disorder and dyslexia. J Am Acad Child Adolesc Psychiatry 31:343-348

Gill M, Daly G, Heron S, Hawi Z, Fitzgerald M (1997) Confirmation of association between attention deficit hyperactivity disorder and a dopamine transporter polymorphism. Mol Psychiatry 2:311-313

Giros B, Jaber M, Jones SR, Wightman RM, Caron MG (1996) Hyperlocomotion and indifference to cocaine and amphetamine in mice lacking the dopamine transporter. Nature 379:606-612

Gizer IR, Ficks C, Waldman ID (2009) Candidate gene studies of ADHD: a meta-analytic review. Hum Genet 126:51-90

Grady DL, Chi HC, Ding YC, Smith M, Wang E, Schuck S, Flodman P, Spence MA, Swanson JM, Moyzis RK (2003) High prevalence of rare dopamine receptor D4 alleles in children diagnosed with attention-deficit hyperactivity disorder. Mol Psychiatry 8:536-545

Gramatte T, Schmidt J (1986) The effect of early postnatal hypoxia on the development of locomotor activity in rats. Biomed Biochim Acta 45:523-529

Haddow JE, Palomaki GE, Allan WC, Williams JR, Knight GJ, Gagnon J, O'Heir CE, Mitchell ML, Hermos RJ, Waisbren SE, Faix JD, Klein RZ (1999) Maternal thyroid deficiency during pregnancy and subsequent neuropsychological development of the child. N Engl J Med 341:549-555

Halperin JM, Newcorn JH, Schwartz ST, Sharma V, Siever LJ, Koda VH, Gabriel S (1997) Age-related changes in the association between serotonergic function and aggression in boys with ADHD. Biol Psychiatry 41:682-689

Hasselmo ME, Linster C, Patil M, Ma D, Cekic M (1997) Noradrenergic suppression of synaptic transmission may influence cortical signal-to-noise ratio. J Neurophysiol 77:3326-3339

Hawi Z, Dring M, Kirley A, Foley D, Kent L, Craddock N, Asherson P, Curran S, Gould A, Richards S, Lawson D, Pay H, Turic D, Langley K, Owen M, O’Donovan M, Thapar A, Fitzgerald M, Gill M (2002) Serotonergic system and attention deficit hyperactivity disorder (ADHD): a potential susceptibility locus at the 5-HT(1B) receptor gene in 273 nuclear families from a multicentre sample. Mol Psychiatry 7:718-725

Hebebrand J, Dempfle A, Saar K, Thiele H, Herpertz-Dahlmann B, Linder M, Kiefl H, Remschmidt H, Hemminger U, Warnke A, Knolker U, Heiser P, Friedel S, Hinney A, Schafer H, Nurnberg P, Konrad K (2006) A genome-wide scan for attention-deficit/ 
hyperactivity disorder in 155 German sib-pairs. Mol Psychiatry 11:196-205

Heffner TG, Seiden LS (1982) Possible involvement of serotonergic neurons in the reduction of locomotor hyperactivity caused by amphetamine in neonatal rats depleted of brain dopamine. Brain Res 244:81-90

Heilman KM, Voeller KK, Nadeau SE (1991) A possible pathophysiologic substrate of attention deficit hyperactivity disorder. J Child Neurol 6(Suppl):S76-S81

Hess EJ, Jinnah HA, Kozak CA, Wilson MC (1992) Spontaneous locomotor hyperactivity in a mouse mutant with a deletion including the Snap gene on chromosome 2. J Neurosci 12:28652874

Hess EJ, Collins KA, Copeland NG, Jenkins NA, Wilson MC (1994) Deletion map of the coloboma $(\mathrm{Cm})$ locus on mouse chromosome 2. Genomics 21:257-261

Hess EJ, Rogan PK, Domoto M, Tinker DE, Ladda RL, Ramer JC (1995) Absence of linkage of apparently single gene mediated ADHD with the human syntenic region of the mouse mutant Coloboma. Am J Med Genet 60:573-579

Hess EJ, Collins KA, Wilson MC (1996) Mouse model of hyperkinesis implicates SNAP-25 in behavioral regulation. J Neurosci 16:3104-3111

Heyser CJ, Wilson MC, Gold LH (1995) Coloboma hyperactive mutant exhibits delayed neurobehavioral developmental milestones. Brain Res Dev Brain Res 89:264-269

Holets VR (1990) The anatomy and function of noradrenaline in the mammalian brain. In: Heal DJ, Mardsen CA (eds) Pharmacology of noradrenaline in the central nervous system. Oxford Medical Publications, Oxford, pp 1-27

Hynd GW, Semrud-Clikeman M, Lorys AR, Novey ES, Eliopulos D (1990) Brain morphology in developmental dyslexia and attention deficit disorder/hyperactivity. Arch Neurol 47:919-926

Hynd GW, Semrud-Clikeman M, Lorys AR, Novey ES, Eliopulos D, Lyytinen H (1991) Corpus callosum morphology in attention deficit-hyperactivity disorder: morphometric analysis of MRI. J Learn Disabil 24:141-146

Hynd GW, Hern KL, Novey ES, Eliopulos D, Marshall R, Gonzalez JJ, Voeller KK (1993) Attention deficit-hyperactivity disorder and asymmetry of the caudate nucleus. J Child Neurol 8:339347

Jaber M, Jones SR, Bosse B, Giros B, Caron MG (1996) Dramatic regulation of tyrosine hydroxylase in the basal ganglia of mice lacking the dopamine transporter. Soc Neurosci Abstr 22:1576

Jaber M, Dumartin B, Sagne C, Haycock JW, Roubert C, Giros B, Bloch B, Caron MG (1999) Differential regulation of tyrosine hydroxylase in the basal ganglia of mice lacking the dopamine transporter. Eur J Neurosci 11:3499-3511

Jones MD, Hess EJ (2003) Norepinephrine regulates locomotor hyperactivity in the mouse mutant coloboma. Pharmacol Biochem Behav 75:209-216

Jones SR, Garris PA, Kilts CD, Wightman RM (1995) Comparison of dopamine uptake in the basolateral amygdaloid nucleus, caudateputamen, and nucleus accumbens of the rat. $\mathrm{J}$ Neurochem 64:2581-2589

Jones SR, Gainetdinov RR, Jaber M, Giros B, Wightman RM, Caron MG (1998a) Profound neuronal plasticity in response to inactivation of the dopamine transporter. Proc Natl Acad Sci USA 95:4029-4034

Jones SR, Gainetdinov RR, Wightman RM, Caron MG (1998b) Mechanisms of amphetamine action revealed in mice lacking the dopamine transporter. J Neurosci 18:1979-1986

Jones MD, Williams ME, Hess EJ (2001a) Abnormal presynaptic catecholamine regulation in a hyperactive SNAP-25-deficient mouse mutant. Pharmacol Biochem Behav 68:669-676
Jones MD, Williams ME, Hess EJ (2001b) Expression of catecholaminergic mRNAs in the hyperactive mouse mutant coloboma. Brain Res Mol Brain Res 96:114-121

Joyce JN, Frohna PA, Neal-Beliveau BS (1996) Functional and molecular differentiation of the dopamine system induced by neonatal denervation. Neurosci Biobehav Rev 20:453-486

Kelsoe JR, Ginns EI, Egeland JA, Gerhard DS, Goldstein AM, Bale SJ, Pauls DL, Long RT, Kidd KK, Conte G (1989) Re-evaluation of the linkage relationship between chromosome $11 \mathrm{p}$ loci and the gene for bipolar affective disorder in the Old Order Amish. Nature 342:238-243

Knight RT, Scabini D, Woods DL (1989) Prefrontal cortex gating of auditory transmission in humans. Brain Res 504:338-342

Kostrzewa RM, Reader TA, Descarries L (1998) Serotonin neural adaptations to ontogenetic loss of dopamine neurons in rat brain. J Neurochem 70:889-898

Kostrzewa RM, Kostrzewa JP, Kostrzewa RA, Nowak P, Brus R (2008) Pharmacological models of ADHD. J Neural Transm 115:287-298

Krause KH, Dresel SH, Krause J, Kung HF, Tatsch K (2000) Increased striatal dopamine transporter in adult patients with attention deficit hyperactivity disorder: effects of methylphenidate as measured by single photon emission computed tomography. Neurosci Lett 285:107-110

Kruesi MJ, Rapoport JL, Hamburger S, Hibbs E, Potter WZ, Lenane M, Brown GL (1990) Cerebrospinal fluid monoamine metabolites, aggression, and impulsivity in disruptive behavior disorders of children and adolescents. Arch Gen Psychiatry 47:419-426

Kustanovich V, Ishii J, Crawford L, Yang M, McGough JJ, McCracken JT, Smalley SL, Nelson SF (2004) Transmission disequilibrium testing of dopamine-related candidate gene polymorphisms in ADHD: confirmation of association of ADHD with DRD4 and DRD5. Mol Psychiatry 9:711-717

Lahmame A, del Arco C, Pazos A, Yritia M, Armario A (1997) Are Wistar-Kyoto rats a genetic animal model of depression resistant to antidepressants? Eur J Pharmacol 337:115-123

LaHoste GJ, Swanson JM, Wigal SB, Glabe C, Wigal T, King N, Kennedy JL (1996) Dopamine D4 receptor gene polymorphism is associated with attention deficit hyperactivity disorder. Mol Psychiatry 1:121-124

Langleben DD, Acton PD, Austin G, Elman I, Krikorian G, Monterosso JR, Portnoy O, Ridlehuber HW, Strauss HW (2002) Effects of methylphenidate discontinuation on cerebral blood flow in prepubescent boys with attention deficit hyperactivity disorder. J Nucl Med 43:1624-1629

Langley K, Marshall L, Van den BM, Thomas H, Owen M, O'Donovan M, Thapar A (2004) Association of the dopamine D4 receptor gene 7-repeat allele with neuropsychological test performance of children with ADHD. Am J Psychiatry 161:133138

Laucht M, Esser G, Baving L, Gerhold M, Hoesch I, Ihle W, Steigleider P, Stock B, Stoehr RM, Weindrich D, Schmidt MH (2000) Behavioral sequelae of perinatal insults and early family adversity at 8 years of age. J Am Acad Child Adolesc Psychiatry 39:1229-1237

Lesch KP, Bengel D, Heils A, Sabol SZ, Greenberg BD, Petri S, Benjamin J, Muller CR, Hamer DH, Murphy DL (1996) Association of anxiety-related traits with a polymorphism in the serotonin transporter gene regulatory region. Science 274:1527-1531

Lesch KP, Timmesfeld N, Renner TJ, Halperin R, Roser C, Nguyen TT, Craig DW, Romanos J, Heine M, Meyer J, Freitag C, Warnke A, Romanos M, Schafer H, Walitza S, Reif A, Stephan DA, Jacob C (2008) Molecular genetics of adult ADHD: converging evidence from genome-wide association and 
extended pedigree linkage studies. J Neural Transm 115:15731585

Levin PM (1938) Restlessness in children. Archives of Neurology and Psychiatry 39:764-770

Levy F, Hay D (2001) Attention, genes, and attention-deficit hyperactivity disorder. Psychology Press, Philadelphia

Li D, Sham PC, Owen MJ, He L (2006) Meta-analysis shows significant association between dopamine system genes and attention deficit hyperactivity disorder (ADHD). Hum Mol Genet 15:2276-2284

Li Q, Lu G, Antonio GE, Mak YT, Rudd JA, Fan M, Yew DT (2007) The usefulness of the spontaneously hypertensive rat to model attention-deficit/hyperactivity disorder (ADHD) may be explained by the differential expression of dopamine-related genes in the brain. Neurochem Int 50:848-857

Lipp HP, Wahlsten D (1992) Absence of the corpus callosum. In: Driscoll P (ed) Genetically defined animal models of neurobehavioural dysfunctions. Birkhäuser, Boston, pp 217-252

Lipp HP, Waanders R, Wolfer DP (1990) A new mouse model of partial and compleat agenesis of the corpus callosum. Soc Neurosci Abstr 16:925

Lou HC, Henriksen L, Bruhn P (1984) Focal cerebral hypoperfusion in children with dysphasia and/or attention deficit disorder. Arch Neurol 41:825-829

Lou HC, Henriksen L, Bruhn P, Borner H, Nielsen JB (1989) Striatal dysfunction in attention deficit and hyperkinetic disorder. Arch Neurol 46:48-52

Lou HC, Henriksen L, Bruhn P (1990) Focal cerebral dysfunction in developmental learning disabilities. Lancet 335:8-11

Luthman J, Fredriksson A, Lewander T, Jonsson G, Archer T (1989) Effects of d-amphetamine and methylphenidate on hyperactivity produced by neonatal 6-hydroxydopamine treatment. Psychopharmacology (Berl) 99:550-557

Luthman J, Brodin E, Sundstrom E, Wiehager B (1990) Studies on brain monoamine and neuropeptide systems after neonatal intracerebroventricular 6-hydroxydopamine treatment. Int J Dev Neurosci 8:549-560

Luthman J, Bassen M, Fredriksson A, Archer T (1997) Functional changes induced by neonatal cerebral 6-hydroxydopamine treatment: effects of dose levels on behavioral parameters. Behav Brain Res 82:213-221

Magara F, Ricceri L, Wolfer DP, Lipp HP (2000) The acallosal mouse strain I/LnJ: a putative model of ADHD? Neurosci Biobehav Rev 24:45-50

Mattes JA (1980) The role of frontal lobe dysfunction in childhood hyperkinesis. Compr Psychiatry 21:358-369

McCarty R, Kirby RF (1982) Spontaneous hypertension and openfield behavior. Behav Neural Biol 34:450-452

McCracken JT, Smalley SL, McGough JJ, Crawford L, Del'Homme M, Cantor RM, Liu A, Nelson SF (2000) Evidence for linkage of a tandem duplication polymorphism upstream of the dopamine D4 receptor gene (DRD4) with attention deficit hyperactivity disorder (ADHD). Mol Psychiatry 5:531-536

McDonald MP, Wong R, Goldstein G, Weintraub B, Cheng SY, Crawley JN (1998) Hyperactivity and learning deficits in transgenic mice bearing a human mutant thyroid hormone beta1 receptor gene. Learn Mem 5:289-301

McIntosh DE, Mulkins RS, Dean RS (1995) Utilization of maternal perinatal risk indicators in the differential diagnosis of ADHD and UADD children. Int J Neurosci 81:35-46

Mefford IN, Potter WZ (1989) A neuroanatomical and biochemical basis for attention deficit disorder with hyperactivity in children: a defect in tonic adrenaline mediated inhibition of locus coeruleus stimulation. Med Hypotheses 29:33-42

Middleton FA, Strick PL (1997a) Cerebellar output channels. Int Rev Neurobiol 41:61-82
Middleton FA, Strick PL (1997b) Dentate output channels: motor and cognitive components. Prog Brain Res 114:553-566

Middleton FA, Strick PL (2001) Cerebellar projections to the prefrontal cortex of the primate. J Neurosci 21:700-712

Mill J, Curran S, Richards S, Taylor E, Asherson P (2004) Polymorphisms in the dopamine D5 receptor (DRD5) gene and ADHD. Am J Med Genet B Neuropsychiatr Genet 125B:38-42

Moser MB, Moser EI, Wultz B, Sagvolden T (1988) Component analyses differentiate between exploratory behaviour of spontaneously hypertensive rats and Wistar Kyoto rats in a twocompartment free-exploration open field. Scand J Psychol 29:200-206

Mueller K, Daly M, Fischer M, Yinnoutsos CT, Bauer L, Barkley RA (2003) Association of the dopamine beta hydroxylase gene with attention deficit hyperactivity disorder: genetic analysis of the Milwaukee longitudinal study. Am J Med Genet 119B:77-85

Myers MM, Whittemore SR, Hendley ED (1981) Changes in catecholamine neuronal uptake and receptor binding in the brains of spontaneously hypertensive rats (SHR). Brain Res 220:325-338

Myers MM, Musty RE, Hendley ED (1982) Attenuation of hyperactivity in the spontaneously hypertensive rat by amphetamine. Behav Neural Biol 34:42-54

Nakajo S, Tsukada K, Omata K, Nakamura Y, Nakaya K (1993) A new brain-specific $14-\mathrm{kDa}$ protein is a phosphoprotein. Its complete amino acid sequence and evidence for phosphorylation. Eur J Biochem 217:1057-1063

Noain D, Avale ME, Wedemeyer C, Calvo D, Peper M, Rubinstein M (2006) Identification of brain neurons expressing the dopamine D4 receptor gene using BAC transgenic mice. Eur J Neurosci 24:2429-2438

Oades RD, Daniels R, Rascher W (1998) Plasma neuropeptide-Y levels, monoamine metabolism, electrolyte excretion and drinking behavior in children with attention-deficit hyperactivity disorder. Psychiatry Res 80:177-186

Okamoto K, Aoki K (1963) Development of a strain of spontaneously hypertensive rats. Jpn Circ J 27:282-293

Ordway GA (1995) Effect of noradrenergic lesions on subtypes of alpha 2-adrenoceptors in rat brain. J Neurochem 64:1118-1126

Papa M, Sellitti S, Sadile AG (2000) Remodeling of neural networks in the anterior forebrain of an animal model of hyperactivity and attention deficits as monitored by molecular imaging probes. Neurosci Biobehav Rev 24:149-156

Pare WP (1989) Stress ulcer and open-field behavior of spontaneously hypertensive, normotensive, and Wistar rats. Pavlov J Biol Sci 24:54-57

Pliszka SR, McCracken JT, Maas JW (1996) Catecholamines in attention-deficit hyperactivity disorder: current perspectives. J Am Acad Child Adolesc Psychiatry 35:264-272

Posner MI, Petersen SE (1990) The attention system of the human brain. Annu Rev Neurosci 13:25-42

Raber J, Mehta PP, Kreifeldt M, Parsons LH, Weiss F, Bloom FE, Wilson MC (1997) Coloboma hyperactive mutant mice exhibit regional and transmitter-specific deficits in neurotransmission. J Neurochem 68:176-186

Rapoport JL, Mikkelsen EJ, Ebert MH, Brown GL, Weise VK, Kopin IJ (1978) Urinary catecholamines and amphetamine excretion in hyperactive and normal boys. J Nerv Ment Dis 166:731-737

Raskin LA, Shaywitz BA, Anderson GM, Cohen DJ, Teicher MH, Linakis J (1983) Differential effects of selective dopamine, norepinephrine or catecholamine depletion on activity and learning in the developing rat. Pharmacol Biochem Behav 19:743-749

Reimherr FW, Wender PH, Ebert MH, Wood DR (1984) Cerebrospinal fluid homovanillic acid and 5-hydroxy-indoleacetic acid in adults with attention deficit disorder, residual type. Psychiatry Res 11:71-78 
Reja V, Goodchild AK, Pilowsky PM (2002) Catecholamine-related gene expression correlates with blood pressures in SHR. Hypertension 40:342-347

Rhee SH, Waldman ID, Hay DA, Levy F (1999) Sex differences in genetic and environmental influences on DSM-III-R attentiondeficit/hyperactivity disorder. J Abnorm Psychol 108:24-41

Roberts DC, Price MT, Fibiger HC (1976) The dorsal tegmental noradrenergic projection: an analysis of its role in maze learning. J Comp Physiol Psychol 90:363-372

Romanos M, Freitag C, Jacob C, Craig DW, Dempfle A, Nguyen TT, Halperin R, Walitza S, Renner TJ, Seitz C, Romanos J, Palmason $\mathrm{H}$, Reif A, Heine M, Windemuth-Kieselbach C, Vogler C, Sigmund J, Warnke A, Schafer H, Meyer J, Stephan DA, Lesch KP (2008) Genome-wide linkage analysis of ADHD using highdensity SNP arrays: novel loci at 5q13.1 and 14q12. Mol Psychiatry 13:522-530

Rubia K, Overmeyer S, Taylor E, Brammer M, Williams SC, Simmons A, Bullmore ET (1999) Hypofrontality in attention deficit hyperactivity disorder during higher-order motor control: a study with functional MRI. Am J Psychiatry 156:891-896

Russell VA (2000) The nucleus accumbens motor-limbic interface of the spontaneously hypertensive rat as studied in vitro by the superfusion slice technique. Neurosci Biobehav Rev 24:133-136

Russell VA, Wiggins TM (2000) Increased glutamate-stimulated norepinephrine release from prefrontal cortex slices of spontaneously hypertensive rats. Metab Brain Dis 15:297-304

Russell V, de Villiers A, Sagvolden T, Lamm M, Taljaard J (1995) Altered dopaminergic function in the prefrontal cortex, nucleus accumbens and caudate-putamen of an animal model of attention-deficit hyperactivity disorder-the spontaneously hypertensive rat. Brain Res 676:343-351

Russell V, de Villiers A, Sagvolden T, Lamm M, Taljaard J (1998) Differences between electrically-, ritalin- and D-amphetaminestimulated release of $[3 \mathrm{H}]$ dopamine from brain slices suggest impaired vesicular storage of dopamine in an animal model of Attention-Deficit Hyperactivity Disorder. Behav Brain Res 94:163-171

Russell V, Allie S, Wiggins T (2000a) Increased noradrenergic activity in prefrontal cortex slices of an animal model for attention-deficit hyperactivity disorder-the spontaneously hypertensive rat. Behav Brain Res 117:69-74

Russell VA, de Villiers AS, Sagvolden T, Lamm MC, Taljaard JJ (2000b) Methylphenidate affects striatal dopamine differently in an animal model for attention-deficit/hyperactivity disorder- the spontaneously hypertensive rat. Brain Res Bull 53:187-192

Russell VA, Sagvolden T, Johansen EB (2005) Animal models of attention-deficit hyperactivity disorder. Behav Brain Funct 1:9

Sadile AG (1993) What can genetic models tell us about behavioral plasticity? Rev Neurosci 4:287-303

Sadile AG, Lamberti C, Siegfried B, Welzl H (1993) Circadian activity, nociceptive thresholds, nigrostriatal and mesolimbic dopaminergic activity in the Naples high- and low-excitability rat lines. Behav Brain Res 55:17-27

Sagvolden T (2000) Behavioral validation of the spontaneously hypertensive rat (SHR) as an animal model of attention-deficit/ hyperactivity disorder (AD/HD). Neurosci Biobehav Rev 24:31-39

Sagvolden T, Metzger MA, Schiorbeck HK, Rugland AL, Spinnangr I, Sagvolden G (1992) The spontaneously hypertensive rat (SHR) as an animal model of childhood hyperactivity (ADHD): changed reactivity to reinforcers and to psychomotor stimulants. Behav Neural Biol 58:103-112

Sagvolden T, Pettersen MB, Larsen MC (1993) Spontaneously hypertensive rats (SHR) as a putative animal model of childhood hyperkinesis: SHR behavior compared to four other rat strains. Physiol Behav 54:1047-1055
Sagvolden T, Aase H, Zeiner P, Berger D (1998) Altered reinforcement mechanisms in attention-deficit/hyperactivity disorder. Behav Brain Res 94:61-71

Sagvolden T, Russell VA, Aase H, Johansen EB, Farshbaf M (2005) Rodent models of attention-deficit/hyperactivity disorder. Biol Psychiatry 57:1239-1247

Schaefer CF, Brackett DJ, Gunn CG, Wilson MF (1978) Behavioral hyperreactivity in the spontaneously hypertensive rat compared to its normotensive progenitor. Pavlov J Biol Sci 13:211-216

Schmahmann JD (2004) Disorders of the cerebellum: ataxia, dysmetria of thought, and the cerebellar cognitive affective syndrome. J Neuropsychiatry Clin Neurosci 16:367-378

Schmahmann JD, Sherman JC (1998) The cerebellar cognitive affective syndrome. Brain 121(Pt 4):561-579

Schwarting RK, Huston JP (1996) The unilateral 6-hydroxydopamine lesion model in behavioral brain research. Analysis of functional deficits, recovery and treatments. Prog Neurobiol 50:275-331

Searle AJ (1966) New mutants, vol 2: Colobomba. Mouse Newsl $35: 27$

Semrud-Clikeman M, Filipek PA, Biederman J, Steingard R, Kennedy D, Renshaw P, Bekken K (1994) Attention-deficit hyperactivity disorder: magnetic resonance imaging morphometric analysis of the corpus callosum. J Am Acad Child Adolesc Psychiatry 33:875-881

Semrud-Clikeman M, Steingard RJ, Filipek P, Biederman J, Bekken K, Renshaw PF (2000) Using MRI to examine brain-behavior relationships in males with attention deficit disorder with hyperactivity. J Am Acad Child Adolesc Psychiatry 39:477-484

Senior SL, Ninkina N, Deacon R, Bannerman D, Buchman VL, Cragg SJ, Wade-Martins R (2008) Increased striatal dopamine release and hyperdopaminergic-like behaviour in mice lacking both alpha-synuclein and gamma-synuclein. Eur J Neurosci 27:947957

Shaywitz BA, Klopper JH, Yager RD, Gordon JW (1976a) Paradoxical response to amphetamine in developing rats treated with 6-hydroxydopamine. Nature 261:153-155

Shaywitz BA, Yager RD, Klopper JH (1976b) Selective brain dopamine depletion in developing rats: an experimental model of minimal brain dysfunction. Science 191:305-308

Shaywitz BA, Cohen DJ, Bowers MB Jr (1977) CSF monoamine metabolites in children with minimal brain dysfunction: evidence for alteration of brain dopamine. A preliminary report. $\mathrm{J}$ Pediatr 90:67-71

Shekim WO, Dekirmenjian H, Chapel JL (1977) Urinary catecholamine metabolites in hyperkinetic boys treated with d-amphetamine. Am J Psychiatry 134:1276-1279

Shekim WO, Dekirmenjian H, Chapel JL (1979) Urinary MHPG excretion in minimal brain dysfunction and its modification by d-amphetamine. Am J Psychiatry 136:667-671

Shekim WO, Javaid J, Davis JM, Bylund DB (1983) Urinary MHPG and HVA excretion in boys with attention deficit disorder and hyperactivity treated with d-amphetamine. Biol Psychiatry 18:707-714

Shekim WO, Sinclair E, Glaser R, Horwitz E, Javaid J, Bylund DB (1987) Norepinephrine and dopamine metabolites and educational variables in boys with attention deficit disorder and hyperactivity. J Child Neurol 2:50-56

Shetty T, Chase TN (1976) Central monoamines and hyperkinase of childhood. Neurology 26:1000-1002

Sieg KG, Gaffney GR, Preston DF, Hellings JA (1995) SPECT brain imaging abnormalities in attention deficit hyperactivity disorder. Clin Nucl Med 20:55-60

Siesser WB, Zhao J, Miller LR, Cheng SY, McDonald MP (2006) Transgenic mice expressing a human mutant beta1 thyroid receptor are hyperactive, impulsive, and inattentive. Genes Brain Behav 5:282-297 
Simson PE, Weiss JM (1987) Alpha-2 receptor blockade increases responsiveness of locus coeruleus neurons to excitatory stimulation. J Neurosci 7:1732-1740

Smidt J, Heiser P, Dempfle A, Konrad K, Hemminger U, Kathofer A, Halbach A, Strub J, Grabarkiewicz J, Kiefl H, Linder M, Knolker U, Warnke A, Remschmidt H, Herpertz-Dahlmann B, Hebebrand J (2003) Formal genetic findings in attention-deficit/hyperactivitydisorder. Fortschr Neurol Psychiatr 71:366-377

Solanto MV (1998) Neuropsychopharmacological mechanisms of stimulant drug action in attention-deficit hyperactivity disorder: a review and integration. Behav Brain Res 94:127-152

Son GH, Chung S, Geum D, Kang SS, Choi WS, Kim K, Choi S (2007) Hyperactivity and alteration of the midbrain dopaminergic system in maternally stressed male mice offspring. Biochem Biophys Res Commun 352:823-829

Speiser Z, Korczyn AD, Teplitzky I, Gitter S (1983) Hyperactivity in rats following postnatal anoxia. Behav Brain Res 7:379-382

Speiser Z, Amitzi-Sonder J, Gitter S, Cohen S (1988) Behavioral differences in the developing rat following postnatal anoxia or postnatally injected AF-64A, a cholinergic neurotoxin. Behav Brain Res 30:89-94

Spivak B, Vered Y, Yoran-Hegesh R, Averbuch E, Mester R, Graf E, Weizman A (1999) Circulatory levels of catecholamines, serotonin and lipids in attention deficit hyperactivity disorder. Acta Psychiatr Scand 99:300-304

Stachowiak MK, Bruno JP, Snyder AM, Stricker EM, Zigmond MJ (1984) Apparent sprouting of striatal serotonergic terminals after dopamine-depleting brain lesions in neonatal rats. Brain Res 291:164-167

Stefanatos GA, Wasserstein J (2001) Attention deficit/hyperactivity disorder as a right hemisphere syndrome. Selective literature review and detailed neuropsychological case studies. Ann N Y Acad Sci 931:172-195

Steffensen SC, Wilson MC, Henriksen SJ (1996) Coloboma contiguous gene deletion encompassing Snap alters hippocampal plasticity. Synapse 22:281-289

Stein DJ, Hollander E, Liebowitz MR (1993) Neurobiology of impulsivity and the impulse control disorders. J Neuropsychiatry Clin Neurosci 5:9-17

Swanson JM, Sunohara GA, Kennedy JL, Regino R, Fineberg E, Wigal T, Lerner M, Williams L, LaHoste GJ, Wigal S (1998) Association of the dopamine receptor D4 (DRD4) gene with a refined phenotype of attention deficit hyperactivity disorder (ADHD): a family-based approach. Mol Psychiatry 3:38-41

Teicher MH, Barber NI, Reichheld JH, Baldessarini RJ, Finklestein SP (1986) Selective depletion of cerebral norepinephrine with 6-hydroxydopamine and GBR-12909 in neonatal rat. Brain Res 395:124-128

Teicher MH, Anderson CM, Polcari A, Glod CA, Maas LC, Renshaw PF (2000) Functional deficits in basal ganglia of children with attention-deficit/hyperactivity disorder shown with functional magnetic resonance imaging relaxometry. Nat Med 6:470-473

Thompson CC, Potter GB (2000) Thyroid hormone action in neural development. Cereb Cortex 10:939-945

Todd RD, Neuman RJ, Lobos EA, Jong YJ, Reich W, Heath AC (2001) Lack of association of dopamine D4 receptor gene polymorphisms with ADHD subtypes in a population sample of twins. Am J Med Genet 105:432-438

Totterdell S, Meredith GE (2005) Localization of alpha-synuclein to identified fibers and synapses in the normal mouse brain. Neuroscience 135:907-913

Totterdell S, Hanger D, Meredith GE (2004) The ultrastructural distribution of alpha-synuclein-like protein in normal mouse brain. Brain Res 1004:61-72

Towle AC, Criswell HE, Maynard EH, Lauder JM, Joh TH, Mueller RA, Breese GR (1989) Serotonergic innervation of the rat caudate following a neonatal 6-hydroxydopamine lesion: an anatomical, biochemical and pharmacological study. Pharmacol Biochem Behav 34:367-374

Tsuda K, Tsuda S, Masuyama Y, Goldstein M (1990) Norepinephrine release and neuropeptide $\mathrm{Y}$ in medulla oblongata of spontaneously hypertensive rats. Hypertension 15:784-790

Vaidya CJ, Austin G, Kirkorian G, Ridlehuber HW, Desmond JE, Glover GH, Gabrieli JD (1998) Selective effects of methylphenidate in attention deficit hyperactivity disorder: a functional magnetic resonance study. Proc Natl Acad Sci U S A 95:1449414499

van der Kooij MA, Glennon JC (2007) Animal models concerning the role of dopamine in attention-deficit hyperactivity disorder. Neurosci Biobehav Rev 31:597-618

Viggiano D, Sadile AG (2000) Hypertrophic A10 dopamine neurones in a rat model of attention-deficit hyperactivity disorder (ADHD). Neuroreport 11:3677-3680

Viggiano D, Grammatikopoulos G, Sadile AG (2002a) A morphometric evidence for a hyperfunctioning mesolimbic system in an animal model of ADHD. Behav Brain Res 130:181-189

Viggiano D, Vallone D, Welzl H, Sadile AG (2002b) The Naples high- and low-excitability rats: selective breeding, behavioral profile, morphometry, and molecular biology of the mesocortical dopamine system. Behav Genet 32:315-333

Viggiano D, Ruocco LA, Pignatelli M, Grammatikopoulos G, Sadile AG (2003a) Prenatal elevation of endocannabinoids corrects the unbalance between dopamine systems and reduces activity in the Naples High Excitability rats. Neurosci Biobehav Rev 27:129_ 139

Viggiano D, Vallone D, Ruocco LA, Sadile AG (2003b) Behavioural, pharmacological, morpho-functional molecular studies reveal a hyperfunctioning mesocortical dopamine system in an animal model of attention deficit and hyperactivity disorder. Neurosci Biobehav Rev 27:683-689

Waldman ID, Rowe DC, Abramowitz A, Kozel ST, Mohr JH, Sherman SL, Cleveland HH, Sanders ML, Gard JM, Stever C (1998) Association and linkage of the dopamine transporter gene and attention-deficit hyperactivity disorder in children: heterogeneity owing to diagnostic subtype and severity. Am J Hum Genet 63:1767-1776

Wang YM, Xu F, Gainetdinov RR, Caron MG (1999) Genetic approaches to studying norepinephrine function: knockout of the mouse norepinephrine transporter gene. Biol Psychiatry 46:1124-1130

Weiss RE, Refetoff S (2000) Resistance to thyroid hormone. Rev Endocr Metab Disord 1:97-108

Weiss RE, Stein MA, Trommer B, Refetoff S (1993) Attention-deficit hyperactivity disorder and thyroid function. J Pediatr 123:539545

Wender PH, Epstein RS, Kopin IJ, Gordon EK (1971) Urinary monoamine metabolites in children with minimal brain dysfunction. Am J Psychiatry 127:1411-1415

Willner P (1991) Behavioural models in psychopharmacology. In: Willner P (ed) Cambridge University Press

Wilson MC (2000) Coloboma mouse mutant as an animal model of hyperkinesis and attention deficit hyperactivity disorder. Neurosci Biobehav Rev 24:51-57

Winsberg BG, Comings DE (1999) Association of the dopamine transporter gene (DAT1) with poor methylphenidate response. J Am Acad Child Adolesc Psychiatry 38:1474-1477

Wyss JM, Fisk G, Van Groen T (1992) Impaired learning and memory in mature spontaneously hypertensive rats. Brain Res 592:135-140

Yeo RA, Hill DE, Campbell RA, Vigil J, Petropoulos H, Hart B, Zamora L, Brooks WM (2003) Proton magnetic resonance spectroscopy investigation of the right frontal lobe in children 
with attention-deficit/hyperactivity disorder. J Am Acad Child Adolesc Psychiatry 42:303-310

Zametkin AJ, Nordahl TE, Gross M, King AC, Semple WE, Rumsey J, Hamburger S, Cohen RM (1990) Cerebral glucose metabolism in adults with hyperactivity of childhood onset. N Engl J Med 323:1361-1366

Zametkin AJ, Liebenauer LL, Fitzgerald GA, King AC, Minkunas DV, Herscovitch P, Yamada EM, Cohen RM (1993) Brain metabolism in teenagers with attention-deficit hyperactivity disorder. Arch Gen Psychiatry 50:333-340

Zarranz JJ, Alegre J, Gomez-Esteban JC, Lezcano E, Ros R, Ampuero I, Vidal L, Hoenicka J, Rodriguez O, Atares B, Llorens V, Gomez TE, del Ser T, Munoz DG, de Yebenes JG (2004) The new mutation, E46K, of alpha-synuclein causes Parkinson and Lewy body dementia. Ann Neurol 55:164-173

Zhang K, Tarazi FI, Baldessarini RJ (2001) Role of dopamine D(4) receptors in motor hyperactivity induced by neonatal 6-hydroxydopamine lesions in rats. Neuropsychopharmacology 25:624632

Zhang K, Davids E, Tarazi FI, Baldessarini RJ (2002a) Serotonin transporter binding increases in caudate-putamen and nucleus accumbens after neonatal 6-hydroxydopamine lesions in rats: implications for motor hyperactivity. Brain Res Dev Brain Res 137:135-138

Zhang K, Tarazi FI, Davids E, Baldessarini RJ (2002b) Plasticity of dopamine D4 receptors in rat forebrain: temporal association with motor hyperactivity following neonatal 6-hydroxydopamine lesioning. Neuropsychopharmacology 26:625-633

Zhou K, Dempfle A, Arcos-Burgos M, Bakker SC, Banaschewski T, Biederman J, Buitelaar J, Castellanos FX, Doyle A, Ebstein RP, Ekholm J, Forabosco P, Franke B, Freitag C, Friedel S, Gill M, Hebebrand J, Hinney A, Jacob C, Lesch KP, Loo SK, Lopera F, McCracken JT, McGough JJ, Meyer J, Mick E, Miranda A, Muenke M, Mulas F, Nelson SF, Nguyen TT, Oades RD, Ogdie MN, Palacio JD, Pineda D, Reif A, Renner TJ, Roeyers H, Romanos M, Rothenberger A, Schafer H, Sergeant J, Sinke RJ, Smalley SL, Sonuga-Barke E, Steinhausen HC, van der ME, Walitza S, Warnke A, Lewis CM, Faraone SV, Asherson P P (2008) Meta-analysis of genome-wide linkage scans of attention deficit hyperactivity disorder. Am J Med Genet B Neuropsychiatry Genet 147B:1392-1398 